Document downloaded from:

http://hdl.handle.net/10251/101703

This paper must be cited as:

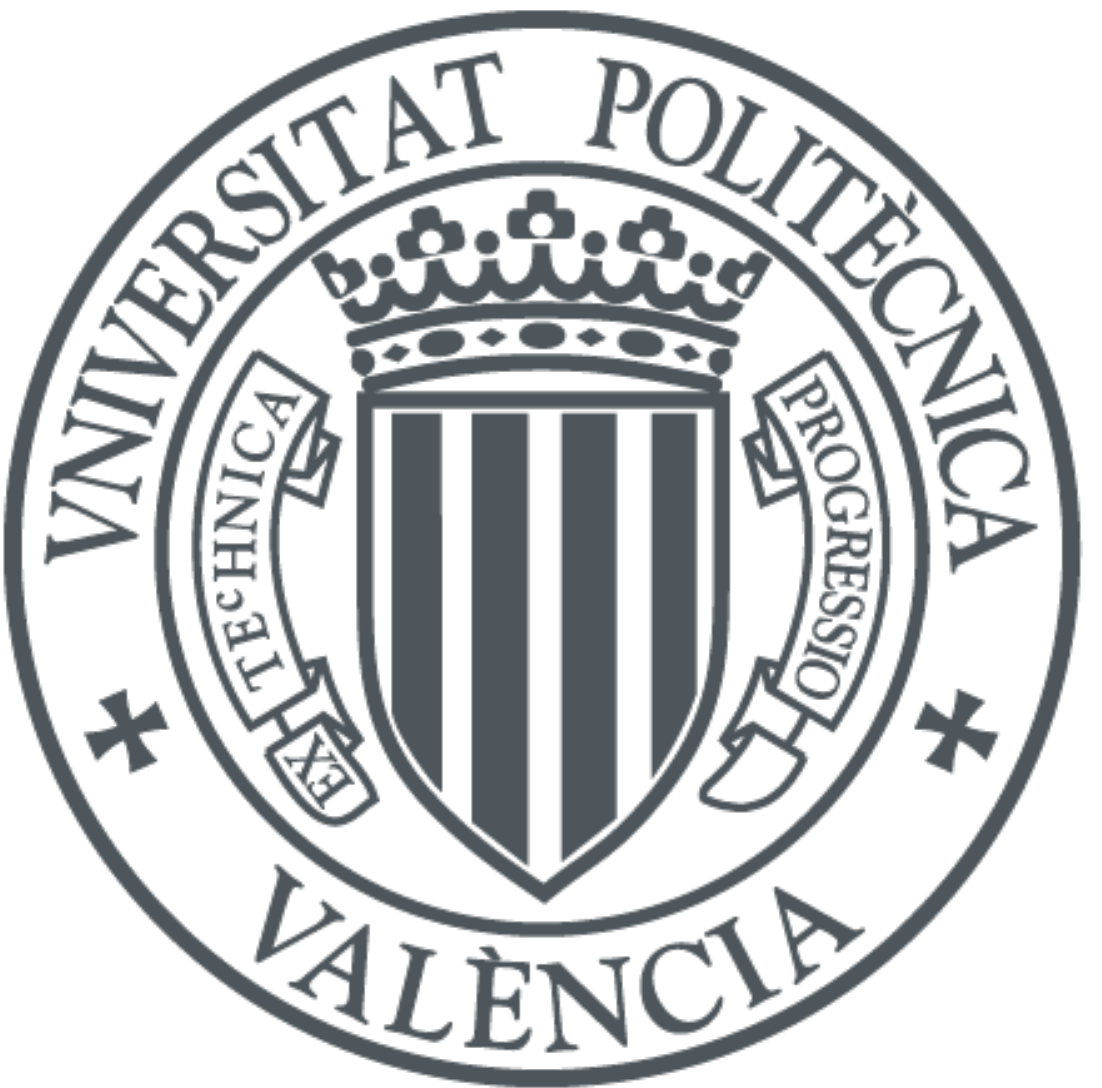

The final publication is available at

https://doi.org/10.1016/j.scitotenv.2017.07.250

Copyright Elsevier

Additional Information 


\title{
Improvement of the drought indicators system in the Júcar River Basin, Spain
}

\author{
Tatiana Ortega Gómez¹; Miguel A. Pérez-Martín²; Teodoro Estrela Monreal12; \\ ${ }^{1}$ Confederación Hidrográfica del Júcar (CHJ) Júcar River Basin Authority, Avd. Blasco Ibáñez nº 48, 46010, \\ Valencia, Spain. \\ ${ }^{2}$ Research Institute of Water and Environmental Engineering (IIAMA), Universitat Politècnica de Valencia, Camino \\ de Vera s/n, 46022, Valencia, Spain. \\ E-mail address: tatiana.ortega@chj.es
}

\begin{abstract}
Droughts are one of the gravest natural threats currently existing in the world and their occurrence and intensity might be exacerbated in the coming years due to climate change. The severe impacts that droughts cause to inland water resources and to the associated socio-economic activities justify the continuous monitoring of the drought. The case study presented shows a practical application of a distributed drought monitoring system implemented in a real river basin district, the Júcar River Basin District $\left(43,000 \mathrm{~km}^{2}\right)$, where drought periods of marked intensity have occurred historically and the climate ranges from humid in the north to semiarid in the south. Five drought indices have been applied: Standardised Precipitation Index (SPI) for meteorological drought; Palmer Drought Severity Index (PDSI) and a new soil moisture index (HI), for edaphic drought; Normalised Difference Vegetation Index (NDVI) for the vegetation activity; and Spanish Status Index (SI), for the operational drought. All indices are standardised to compare them.
\end{abstract}

The relationship between the standardised operational drought index SI and the long-term meteorological indices, SPI-12 or SPI-24, show that in a medium size basin the concept of "prolonged drought" required by the European Commission under the Water Framework Directive could be defined by the use of accumulated precipitation indices. The number of months to be accumulated depends on the size of the basin and the water management system properties. In large basins, such as the Júcar river basin $(22,000$ $\mathrm{km}^{2}$ ), there are significant deviations due to the spatial distribution of the drought. The use of a unique aggregated indicator could hide a significant drought in a specific area, or on the other hand show a nonreal drought. Evolution of drought indices for each water management system must be accompanied by spatially distributed drought maps to better understand the drought status and its evolution.

Key-words: distributed drought monitoring, drought indices, remote sensing, prolonged drought 


\section{Introduction}

Droughts are a natural hazard for the environment, the economy and the social development. Although by itself is not a disaster, whether it becomes one depends on its impacts on society and environment (Wilhite and Buchanan-Smith, 2005). Droughts are present all over the world and affect the arid and semiarid regions and also humid and sub-humid regions (Mishra and Singh, 2010). The spatial extension, from local to regional scale, and the duration in time, from weeks to years, also can be very variable (Andreu et al., 2015). Droughts are a slow-onset natural hazard (Sivakumar et al., 2011), which appears when precipitation is under the normal values during a period of time. The unusual low values of precipitation can be transferred in a fast way (weeks or a few months) to other components of the hydrological cycle (soil moisture, river flows), or on the contrary, in a much slower one (many months or even years) to other components of hydrological cycle such as piezometric levels or groundwater discharges. Due to these characteristics, the Drought Management Plans have demonstrated to be valuable management tools to fight this type of anomalies (Estrela and Vargas, 2011).

The Drought Indicator System has a significant role in the declaration of a drought and in the application of the measures defined in the Drought Management Plans (Estrela and Sancho, 2016). The Drought Indicator System is a powerful tool to support the water managers and final users to understand how and where the drought has been occurring. There is a wide range of drought indicators to determine each type of drought: meteorological, defined as a lack of precipitation over a region for a period of time; hydrological, related to a period with inadequate surface and subsurface water resources for established water uses of a given water resources management system; agricultural, refers to a period with declining soil moisture and consequent crop failure without any reference to surface water resources; and socioeconomic drought, associated with failure of water resources systems to meet water demands (Mishra and Singh, 2010). An extensive revision of drought indices is included in Mishra and Singh (2010) and PedroMonzonís et al. (2015). Besides, remote sensing provides a synoptic view of the Earth, and is an advantageous source of information in evaluating the drought impacts (Quiring and Ganesh, 2010).

The current Drought Indicator System in Spain is formed basically by an operational drought index, the Status Index (SI). This index reflects the amount of available water for the end users in each month, in relation with the amount of available water for that month historically. This index is useful to characterise the socio-economic drought. The index consists of selected control points distributed throughout the Spanish River Basin Districts which include the following information: volume stored in surface reservoirs; groundwater in aquifers; river flow discharges; reservoir inflows and precipitations in those areas where they are significant in relation to the water resources availability to supply the main water demands (Estrela and Vargas, 2011). This index is an aggregated index for socio-economic drought in each water resources system, which should be complemented with a set of other indicators that show the rest of drought types and their spatial variability.

Recently, in 2016, the Royal Decree by which Spanish river basin management plans were approved established that indicator systems of River Basin Authorities should be able to separately diagnose situations of drought and water scarcity. The European Water Framework Directive determines that temporary deterioration in the status of water bodies shall not be in breach of the requirements of this Directive if this is the result of circumstances of natural cause or force majeure which are exceptional or could not reasonably have been foreseen, in particular extreme floods and prolonged droughts, or the result of circumstances due to accidents which could not reasonably have been foreseen. The European Commission (EC, 2007) indicates that the identification of situations of prolonged drought should be performed using natural indicators based on precipitation as the main underlying parameter to indicate 
that it is a 'natural cause or force majeure', and that the circumstances are exceptional or could have not reasonably been foreseen.

This manuscript includes the application of a set of spatially distributed drought indicators in a real case, the Júcar River Basin District (RBD), which is a large district $\left(43,000 \mathrm{~km}^{2}\right)$ formed by the aggregation of several river basins and is located in the Spanish Mediterranean area. The Júcar RBD includes nine water resources systems with different climates, from humid to semiarid, so the drought indices would be tested in different climate conditions. Climate change could be a significant impact in the natural resources of this river basin (Estrela et al., 2012) and drought could be increased in number and intensity in the future (Pérez-Martín et al., 2015). The standardised form of five types of indices are applied: for meteorological drought, the Standardised Precipitation Index (SPI; McKee et al., 1993); for edaphic drought (agricultural) a modified Palmer Drought Severity Index (PDSI, Palmer, 1965) and an expressly created Humidity Index in soil (iHI); for the vegetation response, the standardised Normalised Difference Vegetation Index (iNDVl; Jordan, 1969), and for the operational drought, the standardised Status Index (iSI).

The iSI and iNDV indices are directly derived from observed data and reflect the real situation observed in the river basin. The first one mainly indicates the amount of available water to supply water demands. The second one indicates the vegetation activity in a month iNDVI, in a season (three months) iNDVI-3 or during six consecutive months iNDVI-6, derived from the EOS-Aqua satellite equipped with the MODIS sensor. The meteorological (SPI) and edaphic (PDSI and iHI) indices are derived from precipitation and temperature data. Different monthly accumulations for SPI are considered for the short-term (SPI, SPI-3, SPI-6) and the long-term (SPI-12 and SPI-24). The modified PDSI and the iHI are obtained by the water balance in soil calculated with the Patrical model (Pérez-Martín et al., 2014).

The remainder manuscript includes in section two the Data Set and the indices used. The third section describes the study case results. Discussion is included in the fourth section and finally, the fifth section contains the conclusions. 


\section{Data set and indices used}

The Júcar River Basin District (JRBD) is located in the eastern part of the lberian Peninsula in Spain and is formed by the aggregation of river basins that flow into the Mediterranean Sea. The whole territory includes nine water resources systems (WRS or system), 1) Cenia-Maestrazgo, 2) Mijares-Plana de Castellón, 3) Palancia y los Valles, 4) Turia, 5) Júcar, 6) Serpis, 7) Marina Alta, 8) Marina Baja and 9) Vinalopó-Alacantí, and its total area is around $42.735 \mathrm{~km}^{2}$ (Fig. 1). The Júcar RBD presents a Mediterranean climate. The total annual precipitation is around $500 \mathrm{~mm}$, oscillating between maximum annual values of $780 \mathrm{~mm}$ for the wet years and just over $300 \mathrm{~mm}$ for the dry years. Precipitation in the autumn is almost half of the annual precipitation in the coastal area. The second highest value occurs during the spring and, during the summer, rain is almost non-existent. The same variability can be observed in regards to spatial distribution. There are areas such as Marina Alta with average annual values around $730 \mathrm{~mm}$, and maximum values of $1.325 \mathrm{~mm}$, whereas other areas like Vinalopó-Alacantí receive much less rainfall, with average annual values of $345 \mathrm{~mm}$ and minimum values of $190 \mathrm{~mm}$. Approximately $80 \%$ of the total water received in the form of precipitation is returned to the atmosphere through evaporation, while the remaining $20 \%$ is groundwater and surface runoff (Pérez-Martín et al., 2014). The annual value of potential evapotranspiration for the period 1940/41-2010/11 is $890 \mathrm{~mm} / \mathrm{year}$, actual evapotranspiration is around $409 \mathrm{~mm} / \mathrm{year}$, infiltration is $64 \mathrm{~mm} / \mathrm{year}$, surface runoff is $31 \mathrm{~mm} / \mathrm{year}$ and total runoff is about $95 \mathrm{~mm} /$ year (Pérez-Martín et al., 2014).

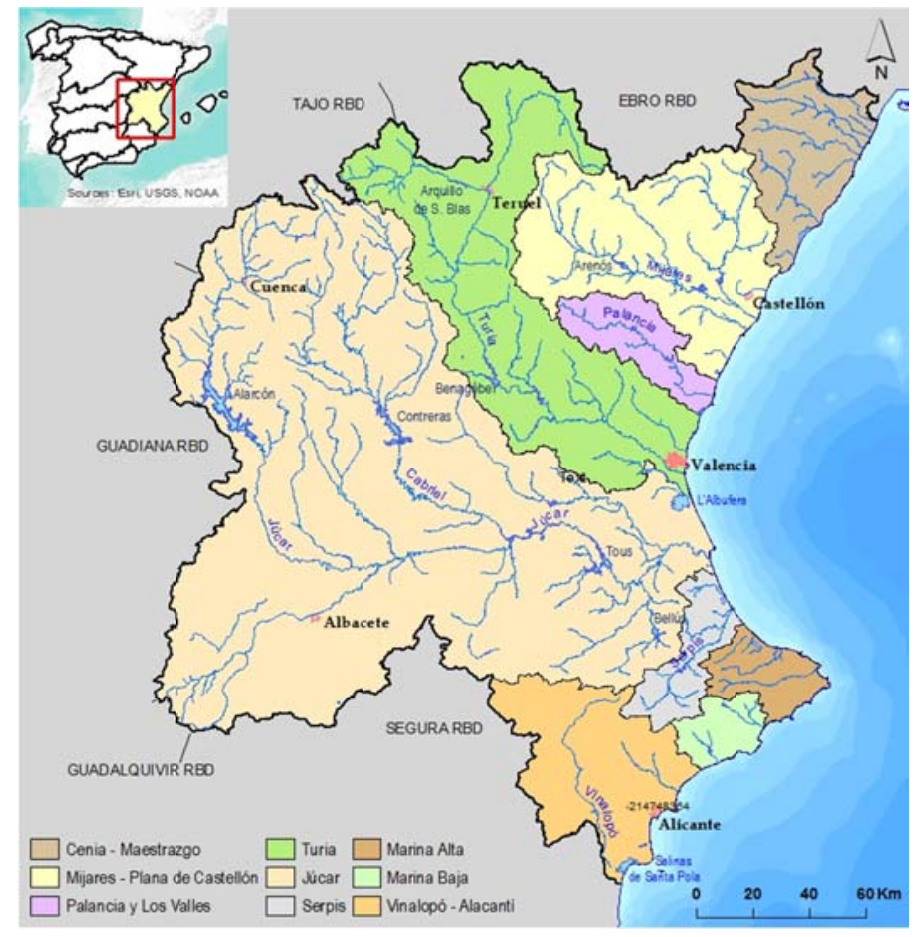

Figure 1. Location of the Jucar River Basin District and the nine water resources systems: 1) Cenia-Maestrazgo, 2) Mijares-Plana de Castellón, 3) Palancia y los Valles, 4) Turia, 5) Júcar, 6) Serpis, 7) Marina Alta, 8) Marina Baja and 9) Vinalopó-Alacantí.

The Júcar RBD has a population of around 5 million people (11\% of the Spanish population) and has an irrigated surface of about 389.000 hectares mainly concentrated in the lower Mijares, Palancia, Turia and Júcar basins, the region of Mancha Oriental, and the irrigated valleys of the Vinalopó and Monegre rivers. This territory has historically been marked by periods of intensive droughts that have compromised the 
management of water resources in the Júcar RBD. The Júcar River Basin Authority guarantees the supply of large populations like the city of Valencia, Albacete and Teruel, and is responsible for the water supply of irrigated areas, and other recreational, industrial and energy water uses, as well as for the compliance with the environmental requirements. In order to satisfy these demands, the District counts on 27 major reservoirs and a total water storage capacity of $3.300 \mathrm{hm}^{3}$. Alarcón, Contreras and Tous are the biggest reservoirs in the river Júcar and Benagéber in the Turia (Fig.1). A further description is included in Ferrer et al. (2012).

The basic geographical unit used in this study is the water resources system (WRS or system). This allows discretising the spatial area of drought in smaller territorial units with a characteristic hydro-meteorological behaviour within the global scope of the District. In accordance with the Spanish Hydrological Planning Regulation, a water resources system is formed by surface water bodies, groundwater bodies, hydraulic infrastructure works and water operation rules that allow establishing the water supply based on the available resources and in compliance with environmental objectives.

\section{$2.1 \quad$ Data set}

Indices are calculated from monthly meteorological data, precipitation and temperature, and satellite data, 15 days Normalised Difference Vegetation Index (NDVI). The meteorological data in real time come from the Júcar Automatic Hydrological Information System (SAlH in Spanish; Estrela, et al., 2007). The SAlH includes 181 rain gauges and 24 thermometers (Fig. 2) with 5-minutes data from 1991 to 2015 and other temporal aggregations, such as daily or monthly time step. The sparse density of available thermometers at the start of the series justified the use of other sources of daily temperature, so the SAlH temperature series has been completed with data from the Spanish Meteorological State Agency (Aemet in Spanish).

Monthly meteorological data coming from $\mathrm{SAlH}$, precipitation and temperature, were previously validated. The validation process includes two processes: the first process is the automatic identification of possible outliers based on the application of two outliers' detection methods: a seasonal-trend decomposition procedure based on LOESS (Cleveland et al., 1990) and a LOF method (Breuning et al., 2000). The second process is a detailed analysis of time series, daily and 5-minutes time step, of the possible monthly outliers detected.

It was found that some of the observations show a pattern of unusual behaviour. In those rain gauges locations where extreme values were recorded, intensity curves were reviewed and the return period for each record was calculated (CEDEX, 1999) and, where appropriate, some anomalies were corrected in collaboration with technicians from the SAlH of the Júcar RBA. 

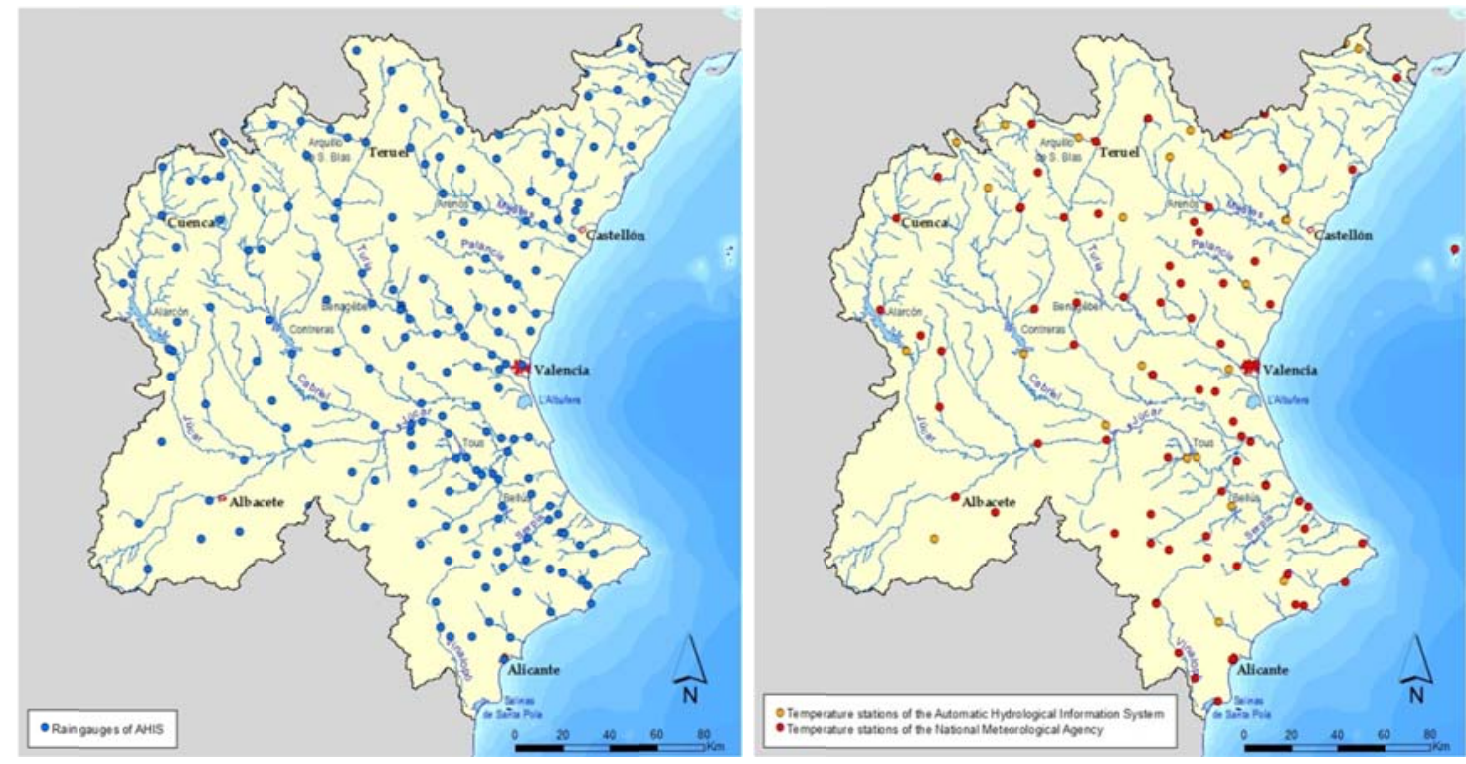

Figure 2. Precipitation and Temperature SAIH network.

The Normalised Difference Vegetation Index, NDVI, comes from the product MYD13Q1 from the EOSAqua satellite which is equipped with the MODIS (Moderate Resolution Imaging Sprectroradiometer) sensor. The satellite data series covers the period 2002-2015. The NDVI values were extracted when the satellite sweeps the surface of the Júcar RBD around $13 \mathrm{~h} 30$ UTC, when vegetation is more stressed. The sensor has a viewing swath width of 2,330 kilometres that covers the entire surface of the Earth every day. The images are supplied in .hdf format, designed to store large amounts of digital data and are geographically referenced to a spherical coordinates system. The temporal resolution is therefore 16 days and the spatial is 250 square metres.

The downloading of the images covering the territory of the Júcar RBD was automated. Since July 2002 it has provided one or two images per month. Each image is formed by the union of four scenes: h17v04 (Scene 1), h17v05 (Scene 2), h18v04 (Scene 3) and h18v05 (Scene 4). Next, the two monthly images (eight scenes) covering the scope of the Júcar RBD were unified in a single raster image averaging NDVI values in each pixel overlap.

The NDVI satellite images provide direct value of this variable originally formulated in accordance with the following relationship between the reflectance detected by the sensor in the spectral bands of red and near-infrared (eq. 1):

$$
N D V I=\frac{\rho N I R-\rho r e d}{\rho N I R+\rho r e d}
$$

Where: $\rho N I R$ is the reflectance detected in the spectral band of near-infrared and $\rho$ red is the reflectance detected in the spectral band of red. 


\section{$2.2 \quad$ Indices used}

Five drought indices are analysed in the manuscript (Table 1): the Standardised Precipitation Index (SPI; McKee et al., 1993), a modified Palmer Drought Severity Index (PDSI, Palmer, 1965), the standardised Normalised Difference Vegetation Index (iNDVI; Jordan, 1969), the standardised Status Index (iSI; Ortega, 2015) derived from the Spanish Status Index (SI) and the expressly created Humidity Index in soil. A detailed review of the indices is included in Mishra and Singh (2010) and Pedro-Monzonís et al. (2015).

\begin{tabular}{|c|c|l|c|}
\hline $\begin{array}{c}\text { Standardised } \\
\text { Index }\end{array}$ & $\begin{array}{c}\text { Type of } \\
\text { drought } \\
\text { monitoring }\end{array}$ & Data source & Process \\
\hline $\begin{array}{c}\text { SPI (McKee et al., 1993) } \\
\text { Short time: SPI, SPI-3, SPI-6 } \\
\text { Long time: SPI-12, SPI-24 }\end{array}$ & Meteorological & SAlH Precipitation stations & $\begin{array}{c}\text { Areal } \\
\text { precipitation }\end{array}$ \\
\hline PDSI (Palmer, 1965) & Edaphic & $\begin{array}{l}\text { SAlH Precipitation and Temperature } \\
\text { stations from and National Meteorological } \\
\text { Agency (Aemet) }\end{array}$ & $\begin{array}{c}\text { Water balance in } \\
\text { soil }\end{array}$ \\
\hline $\begin{array}{c}\text { iHI (Ortega, 2015) } \\
\text { iHI, IHI-3 }\end{array}$ & Edaphic & $\begin{array}{l}\text { Soil moisture obtained by Patrical Water } \\
\text { Balance Model. }\end{array}$ & $\begin{array}{c}\text { Water balance in } \\
\text { soil }\end{array}$ \\
\hline $\begin{array}{c}\text { iNDVI } \\
\text { (derived from NDVI, Jordan, } \\
\text { 1969) } \\
\text { iNDVI, iNDVI-3, iNDVI6 }\end{array}$ & Edaphic & $\begin{array}{l}\text { Greenness of vegetation (NDVI) recorded } \\
\text { by satellite images. MODIS sensor }\end{array}$ & $\begin{array}{c}\text { Standardised } \\
\text { index }\end{array}$ \\
\hline $\begin{array}{c}\text { iSI (Ortega, 2015) } \\
\text { (derived from de SI) }\end{array}$ & Operational & $\begin{array}{l}\text { Reservoir Storages from SAIH Piezometric } \\
\text { levels. Groundwater monitoring network } \\
\text { 3-month Stream-flows from SAlH } \\
\text { 12-month Precipitation from SAlH }\end{array}$ & $\begin{array}{c}\text { Standardised } \\
\text { index }\end{array}$ \\
\hline
\end{tabular}

Table 1. Drought indices and data employed

The first two indices are integrated in the GIS-based monthly water balance model Patrical, which is a hydrological and water quality distributed simulation model (Pérez-Martín et al., 2014; Pérez-Martín et al., 2016). The model is used for the water resources assessment of the river basin, including long-term resources, spatial variability, inter- and intra-annual variability, climate change impact and for the analysis of the temporal evolution of processes with higher inertia, such as nitrate pollution in groundwater bodies. The model has a resolution of 1,000 x 1,000 m and has been applied throughout Spain; its results are used by different Spanish River Basin Authorities. The Patrical model has developed an extension for the creation of fully distributed maps $(1 \mathrm{~km} \times 1 \mathrm{~km})$ of SPI, PDSI and iHI, which can also be processed with the Arc-GIS programme until the desired display is obtained.

Monthly maps of Standardised Precipitation Index for different accumulation periods (SPI-1, SPI-3, SPI-6, SPI-12 y SPI-24) are calculated based on normalised (log-normal distribution function) accumulated precipitation (1, 3, 6, 12 and 24 months). Short accumulation periods determine when the meteorological drought starts and its distribution over the territory. Long-accumulation periods, SPI-12 or SPI-24, reflects the pattern of behaviour of the long-term rainfall, and could also serve in the definition of the concept of "prolonged drought" (EC, 2007) in the Júcar RBD. Also, the Spanish Meteorological State Agency carries out the monthly follow-up of meteorological drought and publishes the SPI index maps for the national scope (www.aemet.es).

Monthly maps of the modified Palmer Drought Severity Index, PDSI, are obtained from the water balance in soil originated by the Patrical model, which is the best calibrated and validated model for the Júcar RBD (Pérez-Martín et al., 2014). The water balance proposed by Palmer (1965) that is developed previously in 
order to calculate the PDSI is replaced by the more accurate water balance for this river basin calculated by the Patrical model. PDSI input data are the monthly precipitation and temperature data.

Drought indices that include precipitation and temperature are currently required due to the changes observed and predicted by climate change in temperature. The PDSI has been used in the Júcar RBD to determine the effect of climate change in the duration and intensity of the current droughts (Pérez-Martín et al., 2015) and also the Standardised Precipitation Evaporation Index (SPEl; Vicente-Serrano et al., 2014), which is a modification of the SPI that includes temperature.

A new drought index based on the variable soil moisture is proposed, the Standardised Humidity Index (iHI). The $\mathrm{iHI}$ has as input data monthly precipitation and temperature. The index, for one month $\mathrm{iHI}$ and for three-average months iHI-3, is calculated from the soil moisture obtained by the Patrical model. The aim of this index is to know, in an easy to understand and direct way, the relative amount of water in the soil, which could be used by the vegetation in a month or in a season (three months) and explore it relationship with the other indices. The iHI-3 reflects the seasonal behaviour of soil moisture, which is associated with medium-term precipitation, and therefore it should be linked with the behaviour of PDSI and iNDVI.

The monthly standardisation (Salas, JD, et al., 1980) is developed for monthly soil moisture or threeaverage soil moisture (eq. 2).

$$
Y_{\mathrm{v}, \mathrm{t}}=\frac{\mathrm{X}_{\mathrm{v}, \mathrm{t}}-\mu_{\mathrm{t}}}{\sigma_{\mathrm{t}}}
$$

Where: $Y_{v, t}$ is the resulting standardised variable for the year $v$ and month $t ; X_{v, t}$ is the original variable; $\mu_{t}$ and $\sigma_{t}$ are respectively the monthly $t(1$ to 12 ) mean and standard deviation of the original variable for the reference period.

Maps of Standardised Normalised Difference Vegetation Index, iNDVI, are obtained by applying the standardisation procedure described above (eq. 2) to the NDVI variable (greenness of vegetation) directly extracted from the satellite images. The Júcar RBD irrigated areas might affect the interpretation in the evolution of the NDVI variable. These areas involve an alteration of the natural hydrological cycle regime due to the artificial supply of water for irrigation, which affects the vegetated land area. The procedure developed for calculating the zonal (water resources system) monthly NDVI values include two versions, with and without the irrigation land existing in the Júcar RBD. Thus, the zonal iNDVI has a second version without the irrigation land $\left(\mathrm{iNDVI}_{\mathrm{w}}\right.$ ). Monthly statistic values of the NDVI variable (range, average, minimum, maximum and standard deviation) were then calculated per water resources system.

The iHI-3, iNDVI-3 and iNDVI-6 indices require three months accumulated values, so it is necessary to use a Python script created for this purpose to automate the task in ArcGIS. Basically, the script consisted of a moving window of 3 items which runs the entire series of the input raster maps (soil moisture and NDVI), creating a new output raster that includes the three-month accumulated original variable. Once the accumulated variable is created, the standardisation process explained above is applied to obtain the spatial distributed iHI-3, iNDVI-3 and iNDVI-6 indices. 
The Standardised Status Index (iSI) was calculated by the monthly standardisation (eq. 2) of the Spanish Status Index (SI). The Status Index (SI) is applied in all the Spanish River Basins and is monthly updated (Fig. 3) in the National Drought Indicator System (MMA, 2007). This system allows making the formal declaration of a drought in the Spanish River basin organisations. This statement implies the entry into force of the drought management plans called "Special action plans in situations of alert and temporary drought", where the water resources systems' exploitation rules and measures to be applied are established in regard to the use of water during the different phases of a drought.

a)

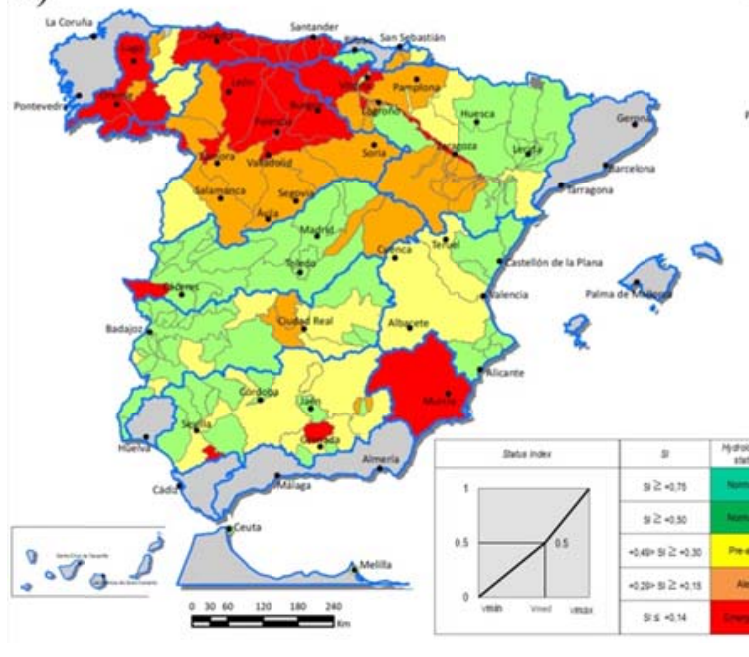

b)

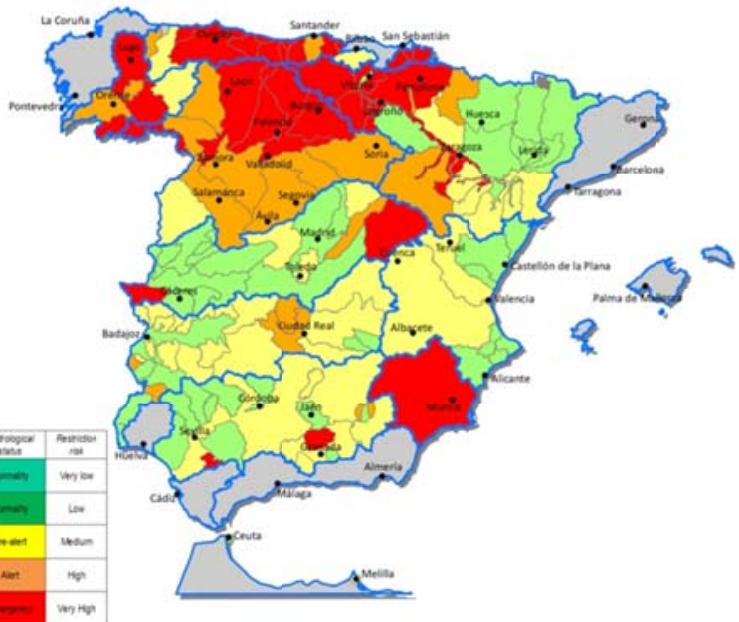

Figure 3. National Drought Indicator System April and May 2017 (Source: www.mapama.es) and Status index definition and risk classification (MMA, 2007).

This indicators system is formed by a distributed network of control points and collects information about reservoir storages, groundwater piezometric levels, stream flows, and precipitation (MMA, 2007; Estrela and Sancho, 2016). Each Spanish river basin organisation has chosen for the SI definition, the indicators (variables) that best describe the water resources systems' behaviour in each territory (Estrela and Vargas, 2011), ensuring a general homogeneity at the national scale. The Status Index is calculated by the following expressions (eq. 3):

$$
\begin{aligned}
& V_{i, t} \geq V_{\text {med }, t} \rightarrow S I_{i, t}=\frac{1}{2}\left[1+\frac{V_{i, t}-V_{\text {med }, t}}{V \text { max }, t-V_{\text {med }, t}}\right] \\
& V_{i, t}<V_{\text {med }, t} \rightarrow S I_{i, t}=\frac{V_{i, t}-V \min , t}{2\left(V_{\text {med }, t}-V \min , t\right)}
\end{aligned}
$$

Where: $V_{i, t}$ is the Status index for the year $i$ and month $t ; V_{i, t}$ is the indicator value for the year $i$ and month $t, V_{\text {med,t, }} V_{\text {max,t }}$ and $V_{\text {min,t }}$ are the monthly ( $t=1$ to 12 ) statistics (mean, maximum and minimum) of the indicator values in the reference period.

The integrated values of SI for the different River Basins or for the entire River Basin District are obtained as the weighted sum of the individual indexes representing the available water resources. The weight of each individual index is based mainly on the amount of water demand that water resources represented by the index is supplying and the level of guarantee required by each water demand unit. The integrated index allows classifying the river basins in four types of hydrologic statuses (normality', pre-alert, alert and emergency) that assess the restriction risks in the various water demand units of the systems 
The SI has therefore an advantage over the meteorological and edaphic indices in the drought management of a water resources system, because it is linked to the demands to be met and the water resources that are used to meet them. In addition, the weighting coefficients and the thresholds defining the types of hydrological status have been estimated taking into account actual water resources systems' deficits.

In the Júcar RBD, the SI summarises drought situations by means of 34 indicators linked to water resources availability to satisfy water demands (Fig. 4a). Areal precipitation gauging stations, aquifer water level monitoring network, stream-flows and reservoir inflows recorded by gauging stations and reservoir storages obtained from SAlH. Those indicators are all weighted at the water resources system scale, depending on the demands they meet, up to a limit lower than $10 \mathrm{hm}^{3} / y e a r$. The results of their monthly application in the Júcar RBD are published in the drought indicators follow-up report of the Júcar River Basin Authority (Fig. 4b), which is accessible through the web page of Júcar River Basin Authority (www.chi.es).
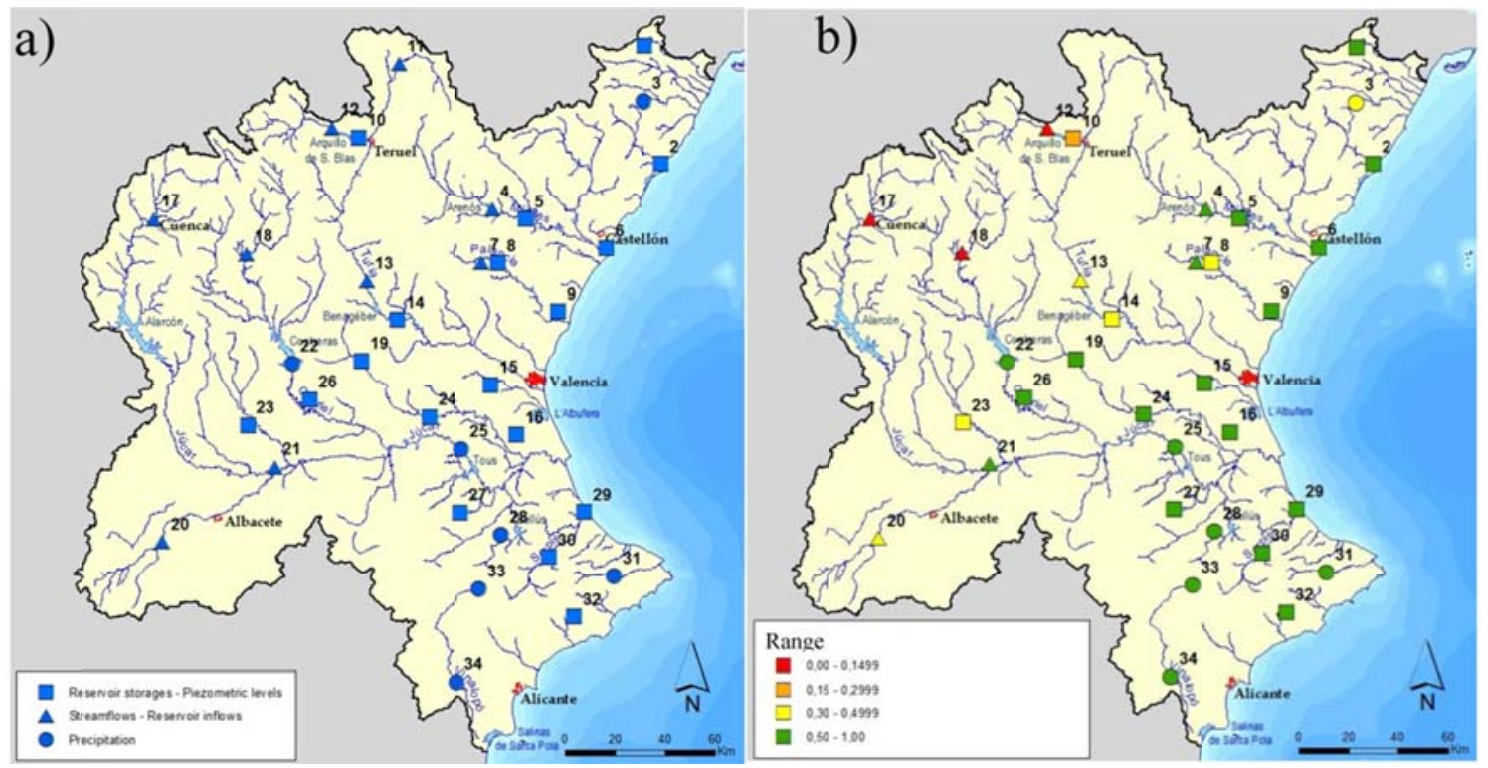

Figure 4. Location of the 34 indicators selected in the Júcar River Basin District. Individual SI May of 2017. 


\section{Results}

The study case shows a practical application of a Drought Monitoring System implemented in a real river basin district, the Júcar River Basin District. Drought indices defined in table 1 are applied to the entire river basin. Droughts have three-dimensional components, spatial distribution (two dimensional) and temporal evolution (third dimension). Two analyses are developed: Mapping Drought Indices along time and aggregated Time Series Drought Indices for a determined area, the water resources system.

Mapping drought indices allows knowing the spatial distribution and the spatial drought evolution, and can help to better understand the drought evolution and its consequences along time.

Time Series of Drought Indices for a specific area, such as the water resources system, are useful to explore the dependency and relationships between different indices. From these results the relationships that may be considered statistically significant, have been established. 


\subsection{Mapping GIS-based indices}

Different colour classifications are adopted to better compare the drought indicators. A more detailed classification to the usually employed by the University of Nebraska-Lincoln is adopted to represent the maps in order to adapt the mapping results to the regional hydro-meteorological conditions of the Júcar River Basin District (Table 2). In the case of SPI, iHI and iHI-3 indices the original value range was modified from seven to nine levels and the normal type was divided into three categories. In the case of PDSI and iNDVI-3 indices a classification is divided into eleven levels, which separates the normal type into five categories.

\begin{tabular}{|l|l|l|}
\hline \multicolumn{1}{|c|}{ SPI and $\mathrm{HII}$} & Classification & Colour \\
\hline & & \\
\hline$-2,00$ and under & extremely dry & \\
\hline$-1,99 a-1,50$ & very dry & \\
\hline$-1,49 a-1,00$ & moderately dry & \\
\hline$-0,99 a-0,50$ & slightly dry & \\
\hline$-0,49 a+0,49$ & near normal & \\
\hline$+0,50 a+0,99$ & slightly wet & \\
\hline$+1,00 a+1,49$ & unusually wet & \\
\hline$+1,50 a+1,99$ & very wet & \\
\hline$+2,00$ and above & extremely wet & \\
\hline & & \\
\hline
\end{tabular}

\begin{tabular}{|l|l|c|}
\hline PDSI and iNDVI & \multicolumn{1}{|c|}{ Classification } & Colour \\
\hline-4.00 and under & extremely dry & \\
\hline$-3.99 a-3.00$ & very dry & \\
\hline$-2,99 a-2.00$ & moderately dry & \\
\hline$-1,99 a-1.00$ & slightly dry & \\
\hline$-0.99 a-0.50$ & incipient dry & \\
\hline$-0.49 a+0.49$ & near normal & \\
\hline$+0.50 a+0.99$ & incipient wet & \\
\hline$+1.00 a+1.99$ & slightly wet & \\
\hline$+2.00 a+2.99$ & unusually wet & \\
\hline$+3.00 a+3.99$ & very wet & \\
\hline+4.00 and above & extremely wet & \\
\hline
\end{tabular}

Table 2. Drought intensity classification, values and colour range, for SPI and iHI (left side) and PDSI and iNDVI (right side).

Recently, a meteorological and edaphic drought occurred in the middle and lower basins of the Júcar RBD during the year 2014 (the anomaly ended in December of 2014). The main systems affected from north to south were: middle and lower Mijares, Turia and Júcar and the entire Vinalopó system. However the upper river basins of these systems (Mijares, Turia and Júcar) were under wet conditions, so the water generation in these areas was normal or above normal in that year.

The spatial distribution of the drought has determinant implications on water management. During that year, 2014, the water resources generation in the upper river basins was not affected. These areas provide the natural inflows to the major reservoirs of the River Basin District. Water demands for crops were increased that year, due to the minor precipitation in the coast and the higher temperature, and water derivations for irrigation are increased around $10 \%$ in respect of previous years (CHJ, 2016). The major water resources systems (Mijares, Turia, Júcar) were not significantly affected by this meteorological-edaphic drought. However, rain-fed irrigation systems (Magro river, Middle Júcar or Vinalopó system) were clearly impacted by the drought.

That year saw the paradox that aggregated drought indicators showed that the year was normal or better than normal, while in large areas of the River Basin District significant impacts due to drought were occurring (Fig. 5). 


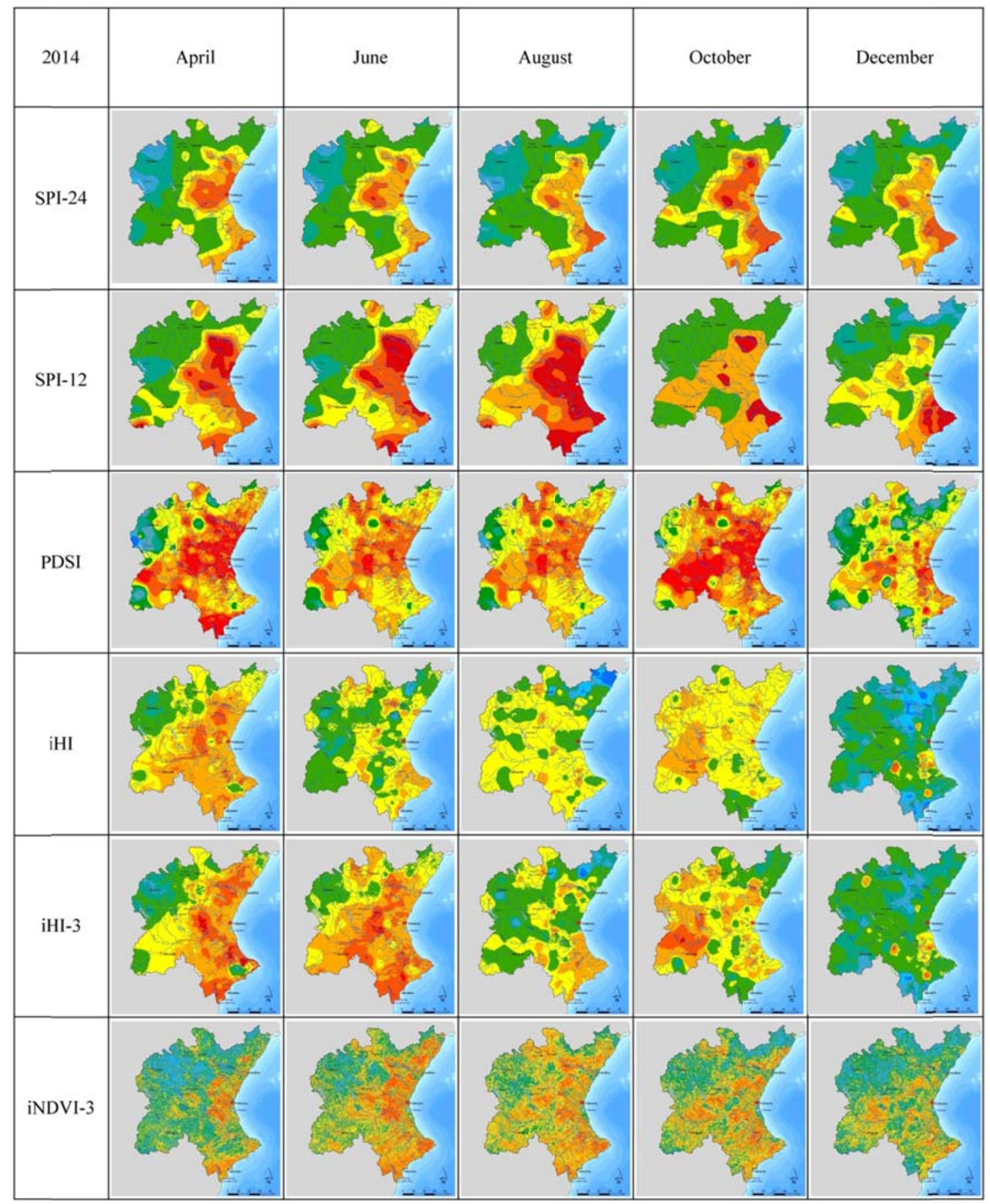

Figure 5. Maps of the drought indices in the dry season of 2014. 


\subsection{Time Series of Drought Indices}

Temporal evolution of the drought indices for Turia and Jucar systems (the largest systems of the Júcar RBD), including the classification of "very dry" and "extremely dry" conditions according to table 2, have been obtained from October 1991 until December 2014 (Fig 6 and Fig. 7). In the case of iNDVI, data series began in 2002 .

Short-term meteorological drought, SPI-3, is very well correlated with the soil moisture, iHI. Both indices have a very similar behaviour along the 23 years studied for the Turia (Fig. 6b) and Jucar (Fig. 7a) systems. So the 3-month accumulated precipitation is a simple and a very good indicator of the soil moisture conditions.

The operational drought index iSI and the long-term meteorological drought, SPI-24, have a similar performance during this period (Fig. $6 \mathrm{~b}$ and Fig. $7 \mathrm{~b}$ ) in both systems, Turia and Júcar. The main reason is that a precipitation deficit prolonged in time is transmitted into the hydrological cycle and finally implies a reduction of water reserves and the available resources for the final users. However, there are some deviations in the Júcar system, the largest system of the Júcar RBD. SPI-24 could be a good index to define the prolonged drought because it only takes into account precipitation data as required by the European Commission (EC, 2007) and additionally it reflects the behaviour of the water resource systems.

In the last normal-dry cycle, from the beginning of 2012 until the end of 2014, many indices -in both systems- show an initial dry condition (iHI and SPI; SPI-24 and iSl; and PDSI, iHI-3) that finally comes to be in a very dry condition (SPI-3 at the end of 2014 and the PDSI during 2014). While the operational drought index iSI of the Turia system also reflects this situation, the iSI of the Júcar system does not reflect it. To understand these deviations in the Júcar system it is necessary to use the distributed maps of the drought indicators (Fig. 5). In the case of the Turia system, the maps (SPI-24, SPI-12 and PDSI) show that the drought extension covers the medium and lower basin and also a part of the upper basin, which is also observed in the iNDVI-3, so in this system there is not a significant deviation between indices. However in the case of the Júcar system, the maps (Fig. 5) show that although drought conditions cover a large extension they do not cover the whole of the river basin, especially the upper basin. If it is also taken into account that the upper basin is the area where a significant part of the water resources of the river basin are generated, then it is possible that an aggregated index for the entire river basin reflects a good situation for the total resources, while it is possible that there is an intensive drought in specific and significant areas inside the basin. The reverse can also happen.

The vegetation index iNDVI-6 has a similar performance to the edaphic drought indicator PDSI, in both systems analysed, Júcar (Fig. 6c) and Turia (Fig. 7c). This behaviour is slightly worse with the iHI-3 index. 

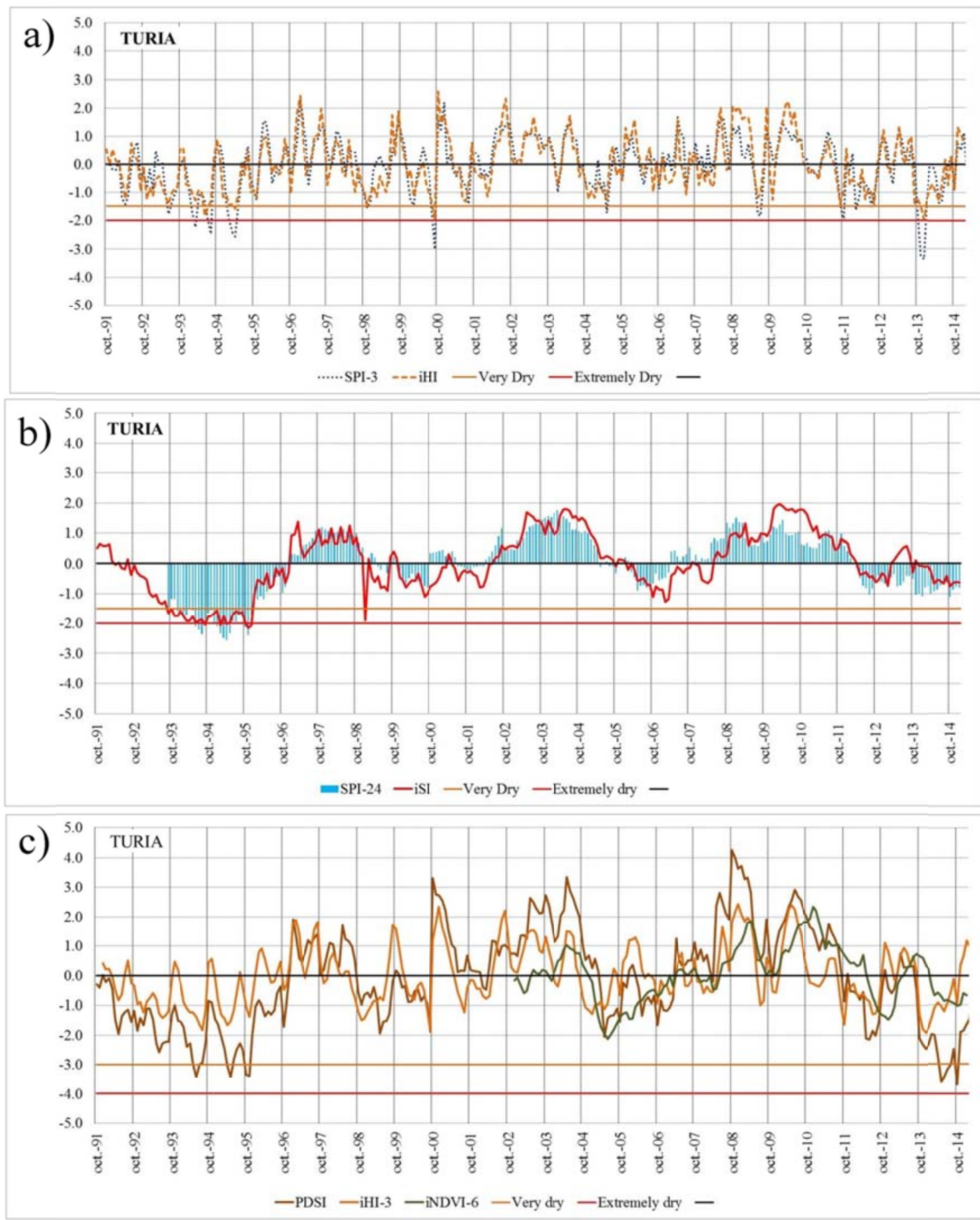

Figure 6. Time series of drought indices for the Turia system. a) Relationship between soil moisture index iHI and short-term meteorological index SPI-3. b) Relationship between operational index iSI and long-term meteorological index SPI-24. c) Relationship between edaphic indices PDSI and $\mathrm{iHI}-3$ and vegetation index iNDVI-6. 

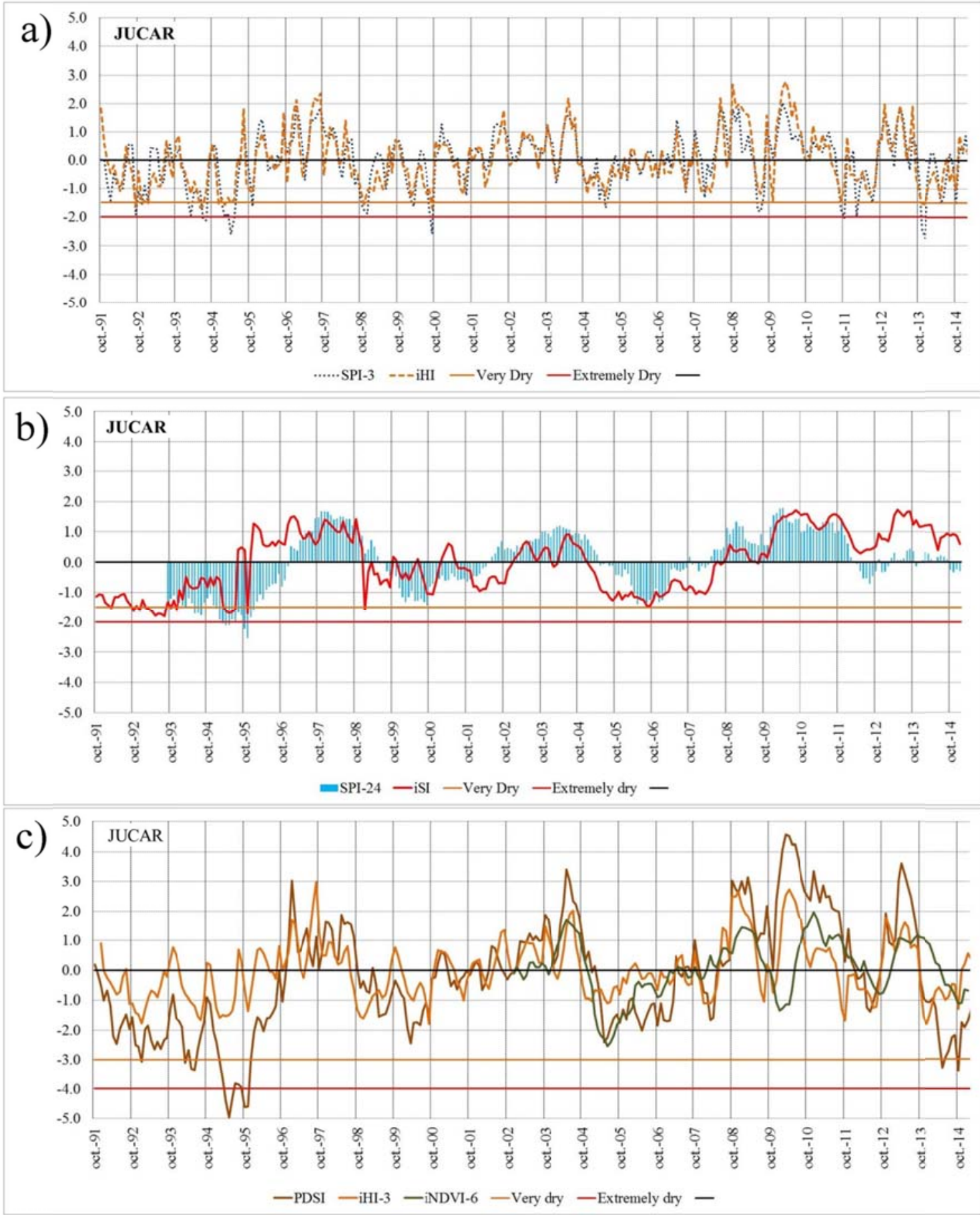

Figure 7. Time series of drought indices for the Júcar system. a) Relationship between soil moisture index iHI and short-term meteorological index SPI-3. b) Relationship between operational index iSl and long-term meteorological index SPI-24. c) Relationship between edaphic indices PDSI and iHI-3 and vegetation index iNDVI-6. 
Monthly evolution of the different drought indices for the Júcar system is presented through a matrix (Table 3). The matrix includes for each index, iSI, SPI-24 SPI-12 SPI-6, SPI-3, PDSI, iHI, iHI-3, iNDVI, iNDVI-3 and iNDVI-6, the numerical value and the class in which it is included based on Table 2 . This table is an easy understanding tool to know the beginning and the ending of the droughts, their intensity and scope: meteorological, edaphic or operational.

In the Júcar system there is an extreme dry period during the water years 1993/94-1994/95 and two very dry periods, one of two years 1998/99-1999/2000 and another of three years 2004/05-2006/07. The greater manifested drought occurred in the early nineties (1994-1995) when all standardised indices for different time offsets reveal the existence of "extremely dry" meteorological, edaphic and operational conditions persistent over around 24 months. Other shorter dry periods are detected in the years 2011/12 and 2013/14.

For these cases, the indices SPI-3, iHI and iNDVI are the first to detect the onset of a dry period (October 2004, June 2009, August 2011), with an estimated anticipation of 5 to 8 months compared to the SPI-12 and PDSI, (October 2004, August 2011), and of 10 to 18 months when compared to the SPI-24 (October 2004, August 2011). These soil or short-term meteorological indices have demonstrated their anticipation in drought detection, respectively to other indices studied for long-term meteorological (SPI-12, SPI-24), edaphic (PDSI) or operational (iSI), so they improve the drought risk detection. 


\begin{tabular}{|c|c|c|c|c|c|c|c|c|c|c|c|}
\hline Month & $\underline{\underline{\square}}$ & $\begin{array}{l}\frac{d}{N} \\
\frac{D}{C}\end{array}$ & $\frac{7}{\frac{7}{b}}$ & $\frac{\varphi}{\frac{\varphi}{n}}$ & $\frac{m}{\frac{m}{n}}$ & $\bar{Q}$ & $\stackrel{I}{\underline{I}}$ & $\stackrel{m}{\underline{\underline{I}}}$ & 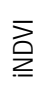 & $\stackrel{m}{\stackrel{m}{p}}$ & $\overbrace{\underline{\underline{n}}}^{\varphi}$ \\
\hline oct-93 & -1.54 & -1.23 & -0.40 & 0.11 & 0.13 & -1.29 & 0.66 & 0.35 & & & \\
\hline nov-93 & -1.28 & -1.10 & 0.02 & 0.50 & 0.37 & -0.83 & \begin{tabular}{|l|l|} 
& 0.88
\end{tabular} & \begin{tabular}{|l|l|} 
\\
\end{tabular} & & & \\
\hline dec-93 & -1.61 & -1.31 & -0.40 & -0.22 & 0.00 & -1.61 & \begin{tabular}{|l|} 
\\
\end{tabular} & \begin{tabular}{|l|}
0.50 \\
\end{tabular} & & & \\
\hline jan-94 & -0.93 & -1.35 & -0.29 & -0.56 & -0.65 & -1.71 & -0.41 & 0.01 & & & \\
\hline feb-94 & -1.24 & -1.46 & -0.91 & -0.69 & -1.37 & -1.89 & $\mid-0.76$ & \begin{tabular}{|l|}
-0.54 \\
\end{tabular} & & & \\
\hline mar-94 & -0.48 & -1.50 & -1.27 & -1.09 & -1.94 & -3.11 & -1.18 & $|-0.81|$ & & & \\
\hline apr-94 & -0.77 & -1.21 & -0.88 & -1.10 & -1.07 & $\mid-2.66$ & \begin{tabular}{|l|}
-0.76 \\
\end{tabular} & \begin{tabular}{|l|}
-0.94 \\
\end{tabular} & & & \\
\hline may-94 & -0.87 & -1.37 & $\begin{array}{l}-0.82 \\
\end{array}$ & -1.60 & -1.12 & -3.32 & -1.07 & -1.08 & & & \\
\hline jun-94 & -0.87 & -1.72 & -1.25 & -1.90 & -1.10 & $|-3.34|$ & -1.67 & -1.19 & & & \\
\hline jul-94 & -0.83 & -1.69 & -1.47 & -2.07 & -2.09 & -2.61 & $\mid-1.61$ & -1.55 & & & \\
\hline aug-94 & -0.52 & -1.77 & -1.46 & -2.08 & -2.12 & -2.19 & $\mid-1.06$ & $\mid-1.67$ & & & \\
\hline sep-94 & -0.55 & -1.35 & -1.23 & -1.14 & -0.15 & \begin{tabular}{|l|}
-1.73 \\
\end{tabular} & \begin{tabular}{|l|}
0.05 \\
\end{tabular} & \begin{tabular}{|l|}
-0.99 \\
\end{tabular} & & & \\
\hline oct-94 & -0.83 & -1.19 & -1.20 & -0.71 & 0.56 & \begin{tabular}{|l|}
-0.91 \\
\end{tabular} & \begin{tabular}{|l|l|}
0.58 \\
\end{tabular} & 0.25 & & & \\
\hline nov-94 & -0.50 & -1.05 & -1.54 & -0.32 & 0.47 & -1.12 & \begin{tabular}{|l|l|} 
& -0.27 \\
\end{tabular} & \begin{tabular}{|l|l|}
0.16 \\
\end{tabular} & & & \\
\hline dec-94 & -0.77 & -1.44 & -1.75 & -0.65 & -0.55 & -2.05 & -1.58 & $|-0.63|$ & & & \\
\hline jan-95 & -0.47 & -1.54 & -2.03 & -0.70 & -1.56 & -2.39 & -1.36 & -1.27 & & & \\
\hline feb-95 & -0.60 & -1.93 & -2.01 & -0.81 & -2.00 & -3.05 & $\mid-1.59$ & $\mid-1.59$ & & & \\
\hline mar-95 & -1.46 & -2.04 & -1.69 & -1.48 & -1.87 & $\mid-3.72$ & -1.32 & $\mid-1.50$ & & & \\
\hline apr-95 & -1.64 & -2.12 & -2.28 & -2.52 & -2.59 & \begin{tabular}{|l|}
-4.40 \\
\end{tabular} & -1.52 & \begin{tabular}{|l|}
-1.53 \\
\end{tabular} & & & \\
\hline may-95 & -1.70 & -2.10 & -1.89 & -2.58 & -2.07 & -4.97 & -1.38 & \begin{tabular}{|l|}
-1.49 \\
\end{tabular} & & & \\
\hline jun-95 & -1.67 & -1.92 & -1.37 & -1.63 & -0.81 & -4.29 & $\mid 0.05$ & -1.35 & & & \\
\hline jul-95 & -1.56 & -1.99 & -1.30 & -1.48 & 0.10 & $|-3.81|$ & -0.13 & $|-0.85|$ & & & \\
\hline aug-95 & 0.41 & -1.68 & -0.69 & -0.33 & 1.31 & \begin{tabular}{|l|} 
\\
\end{tabular} & \begin{tabular}{|l|}
1.83 \\
\end{tabular} & \begin{tabular}{|l|l|}
0.69 \\
\end{tabular} & & & \\
\hline sep-95 & 0.49 & -1.76 & -1.21 & -0.67 & 0.18 & $|-3.95|$ & -0.90 & \begin{tabular}{|l|} 
\\
\end{tabular} & & & \\
\hline oct-95 & 0.40 & -2.23 & -1.93 & -0.58 & -0.65 & $\mid-4.62$ & -1.08 & -0.65 & & & \\
\hline nov-95 & -1.71 & -2.53 & -2.06 & -0.26 & -1.64 & \begin{tabular}{|l|}
-4.61 \\
\end{tabular} & -1.17 & \begin{tabular}{|l|}
-1.36 \\
\end{tabular} & & & \\
\hline dec-95 & 0.31 & -1.84 & -0.96 & \begin{tabular}{|l|}
0.27 \\
\end{tabular} & 0.39 & \begin{tabular}{|c|}
-3.02 \\
\end{tabular} & 0.26 & -0.80 & & & \\
\hline jan-96 & 1.26 & -1.62 & -0.39 & 0.71 & 1.29 & -2.04 & \begin{tabular}{|l|l|}
0.59 \\
\end{tabular} & -0.04 & & & \\
\hline feb-96 & 1.18 & -1.31 & -0.08 & 0.34 & 1.44 & -1.56 & $\mid 0.95$ & \begin{tabular}{|l|l|} 
\\
\end{tabular} & & & \\
\hline mar-96 & 1.03 & -1.08 & 0.06 & 0.63 & 0.68 & -1.68 & \begin{tabular}{|l|l|} 
\\
\end{tabular} .47 & \begin{tabular}{|l|l|}
0.74 \\
\end{tabular} & & & \\
\hline apr-96 & 0.59 & -1.24 & 0.21 & 0.69 & -0.40 & -2.03 & -0.06 & 0.55 & & & \\
\hline may-96 & 0.53 & -0.93 & 0.47 & 0.81 & -0.21 & \begin{tabular}{|l|}
-1.61 \\
\end{tabular} & \begin{tabular}{|l|}
0.17 \\
\end{tabular} & 0.26 & & & \\
\hline jun-96 & 0.54 & -0.81 & 0.22 & 0.23 & -0.27 & $\mid-1.59$ & -0.38 & -0.06 & & & \\
\hline jul-96 & 0.68 & -0.74 & 0.24 & -0.27 & 0.18 & -1.41 & \begin{tabular}{|l|l|} 
& -0.19 \\
\end{tabular} & -0.07 & & & \\
\hline aug-96 & 0.54 & -0.70 & -0.07 & $\begin{array}{l}-0.42 \\
\end{array}$ & -0.14 & \begin{tabular}{|l|}
-1.19 \\
\end{tabular} & $\mid-0.16$ & -0.30 & & & \\
\hline sep-96 & 0.72 & -0.40 & 0.61 & 0.51 & 1.12 & \begin{tabular}{|l|}
-0.04 \\
\end{tabular} & \begin{tabular}{|l|} 
\\
\end{tabular} & 0.80 & & & \\
\hline oct-96 & 0.62 & -0.80 & 0.56 & 0.14 & 0.21 & -1.05 & \begin{tabular}{|l|}
-0.81 \\
\end{tabular} & \begin{tabular}{|l|}
-0.03 \\
\end{tabular} & & & \\
\hline nov-96 & 0.59 & -0.59 & 0.85 & 0.43 & 0.66 & -0.29 & 0.35 & 0.25 & & & \\
\hline dec-96 & 1.24 & -0.13 & 0.77 & 1.17 & 0.70 & 0.96 & 1.63 & 0.60 & & & \\
\hline jan-97 & 1.46 & 0.53 & 1.24 & 1.78 & 1.96 & \begin{tabular}{|l|}
3.03 \\
\end{tabular} & 2.12 & \begin{tabular}{|l|l|} 
\\
\end{tabular} & & & \\
\hline feb-97 & 1.50 & 0.45 & 0.90 & 1.57 & 1.39 & 1.89 & \begin{tabular}{|l|l|}
0.71 \\
\end{tabular} & \begin{tabular}{|l|}
1.58 \\
\end{tabular} & & & \\
\hline mar-97 & 1.33 & 0.37 & 0.72 & \begin{tabular}{|l|}
0.73 \\
\end{tabular} & 0.57 & 0.59 & -0.58 & \begin{tabular}{|l|}
0.86 \\
\end{tabular} & & & \\
\hline apr-97 & 0.94 & 0.73 & 1.00 & 1.21 & -0.72 & \begin{tabular}{|l|}
0.66 \\
\end{tabular} & \begin{tabular}{|l|}
-0.17 \\
\end{tabular} & 0.02 & & & \\
\hline may-97 & 0.78 & 0.88 & 0.95 & 1.03 & 0.36 & 1.03 & $\mid 0.27$ & -0.27 & & & \\
\hline jun-97 & 0.80 & 0.95 & 1.32 & 1.23 & 1.42 & 1.41 & 1.57 & 0.35 & & & \\
\hline jul-97 & 0.99 & 1.02 & 1.39 & 0.61 & 1.41 & 0.59 & 2.19 & \begin{tabular}{|l|l|} 
\\
\end{tabular} & & & \\
\hline aug-97 & 0.81 & 1.00 & 1.53 & 1.27 & 1.64 & \begin{tabular}{|l|} 
\\
\end{tabular} & 2.11 & 2.18 & & & \\
\hline sep-97 & 0.59 & 1.43 & 1.68 & 2.30 & 1.86 & 1.12 & 2.35 & 2.99 & & & \\
\hline oct-97 & 0.71 & 1.47 & 1.75 & 1.85 & 1.12 & \begin{tabular}{|l|} 
\\
\end{tabular} & -0.54 & \begin{tabular}{|l|l} 
\\
\end{tabular} & & & \\
\hline
\end{tabular}

\begin{tabular}{|c|c|c|c|c|c|c|c|c|c|c|c|}
\hline Month & $\underline{\underline{\underline{D}}}$ & $\begin{array}{l}\frac{d}{d} \\
\frac{d}{2}\end{array}$ & $\frac{7}{\frac{7}{2}}$ & $\frac{\varphi}{\frac{\varphi}{n}}$ & $\frac{m}{d}$ & $\begin{array}{l}\overline{8} \\
\bar{a}\end{array}$ & $\underline{I}$ & $\stackrel{m}{\underline{\underline{P}}}$ & 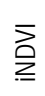 & $\sum_{i=1}^{m}$ & 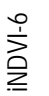 \\
\hline nov-97 & 1.06 & 1.67 & 1.78 & 1.77 & 0.81 & 0.70 & 0.32 & 0.49 & & & \\
\hline dec-97 & 1.38 & 1.66 & 1.90 & 1.89 & 0.78 & 1.63 & 1.18 & 0.48 & & & \\
\hline jan-98 & 1.34 & 1.65 & 1.46 & 1.46 & 1.17 & 1.59 & 0.91 & 0.94 & & & \\
\hline feb-98 & 1.22 & 1.53 & 1.65 & 1.19 & 0.85 & 1.37 & 0.60 & 0.92 & & & \\
\hline mar-98 & 1.11 & 1.40 & 1.63 & 0.28 & -0.22 & 0.44 & -0.21 & 0.50 & & & \\
\hline apr-98 & 0.98 & 1.43 & 1.30 & 0.50 & -0.65 & 0.33 & 0.05 & 0.18 & & & \\
\hline may-98 & 0.99 & 1.51 & 1.34 & 0.69 & 0.44 & 1.88 & \begin{tabular}{|l|l|}
1.41 \\
\end{tabular} & 0.27 & & & \\
\hline jun-98 & 1.33 & 1.48 & 1.07 & 0.23 & 0.61 & 1.56 & 0.19 & 0.60 & & & \\
\hline jul-98 & 0.94 & 1.40 & 0.89 & 0.01 & 0.73 & 1.62 & -0.60 & 0.81 & & & \\
\hline aug-98 & 0.81 & 1.41 & 0.63 & -0.06 & -0.89 & 1.53 & -0.35 & -0.20 & & & \\
\hline sep-98 & 0.63 & 1.20 & 0.21 & 0.11 & -0.61 & 1.15 & \begin{tabular}{|l|}
-0.49 \\
\end{tabular} & -0.63 & & & \\
\hline oct-98 & 1.41 & 1.24 & 0.16 & -0.43 & \begin{tabular}{|l|}
-1.54 \\
\end{tabular} & \begin{tabular}{|l|l|} 
& 0.08 \\
\end{tabular} & -1.16 & -1.30 & & & \\
\hline $\begin{array}{l}\text { nov-98 } \\
\end{array}$ & 0.89 & 0.97 & \begin{tabular}{|c|}
-0.43 \\
\end{tabular} & -2.56 & -1.75 & -0.59 & \begin{tabular}{|l|}
-1.56 \\
\end{tabular} & -1.55 & & & \\
\hline dec-98 & 0.45 & 0.87 & -0.78 & -1.92 & -1.88 & -0.37 & -1.07 & -1.60 & & & \\
\hline jan-99 & -1.59 & 0.30 & -1.18 & -1.59 & -0.60 & -0.70 & -1.00 & -1.39 & & & \\
\hline feb-99 & -0.31 & 0.42 & -1.29 & -1.72 & -0.10 & -0.76 & $\mid-1.11$ & -1.13 & & & \\
\hline mar-99 & 0.01 & 0.74 & -0.53 & -0.88 & 0.22 & 0.08 & -0.40 & -0.88 & & & \\
\hline apr-99 & -0.41 & 0.50 & -0.60 & -0.28 & 0.23 & -0.50 & \begin{tabular}{|l|}
-0.68 \\
\end{tabular} & -0.76 & & & \\
\hline may-99 & -0.38 & 0.19 & -1.33 & -0.21 & -0.07 & -1.54 & \begin{tabular}{|l|}
-1.03 \\
\end{tabular} & -0.67 & & & \\
\hline jun-99 & -0.74 & -0.04 & \begin{tabular}{|c|}
-1.27 \\
\end{tabular} & -0.51 & \begin{tabular}{|l|}
-1.03 \\
\end{tabular} & -1.50 & \begin{tabular}{|l|}
-0.79 \\
\end{tabular} & -0.94 & & & \\
\hline jul-99 & -0.61 & -0.05 & -0.99 & -0.10 & -0.27 & -1.45 & 0.50 & -0.81 & & & \\
\hline aug-99 & -0.57 & -0.31 & -1.00 & $-0.11 \mid$ & 0.22 & -1.18 & $|-0.45|$ & -0.43 & & & \\
\hline sep-99 & -0.82 & -0.44 & -0.70 & -0.35 & 0.71 & -0.79 & $\mid 0.72$ & 0.35 & & & \\
\hline oct-99 & 0.18 & -0.13 & -0.13 & 0.24 & 0.69 & -0.35 & 0.61 & 0.77 & & & \\
\hline nov-99 & 0.07 & -0.47 & -0.09 & 0.34 & 0.41 & -0.54 & 0.01 & 0.49 & & & \\
\hline $\begin{array}{ll}\text { dec-99 } \\
\end{array}$ & -0.35 & -0.86 & \begin{tabular}{|c|}
-0.38 \\
\end{tabular} & 0.11 & -0.42 & -0.83 & $\mid-0.42$ & 0.03 & & & \\
\hline jan-00 & -0.56 & -1.16 & \begin{tabular}{|c|}
-0.43 \\
\end{tabular} & -0.31 & -1.00 & -0.96 & $\mid-0.31$ & -0.28 & & & \\
\hline feb-00 & -0.35 & -1.33 & -0.66 & -0.66 & -1.42 & -1.93 & $\mid-1.33$ & -0.74 & & & \\
\hline mar-00 & -0.59 & -1.17 & -1.07 & -1.28 & -1.64 & -2.44 & -1.06 & -0.93 & & & \\
\hline apr-00 & -0.37 & -0.96 & -0.69 & -0.95 & -0.45 & -1.75 & \begin{tabular}{|l|}
-0.34 \\
\end{tabular} & -1.01 & & & \\
\hline may-00 & -0.09 & -1.29 & -0.27 & -0.49 & 0.31 & -1.74 & -0.14 & -0.66 & & & \\
\hline jun-00 & 0.10 & -1.26 & -0.43 & -0.69 & 0.21 & -1.83 & \begin{tabular}{|l|}
-0.82 \\
\end{tabular} & -0.43 & & & \\
\hline jul-00 & -0.31 & -1.23 & -0.65 & -0.70 & -0.41 & -1.34 & -1.19 & -0.60 & & & \\
\hline aug-00 & -0.70 & -1.33 & -0.63 & -0.36 & -1.62 & $\mid-1.04$ & $\mid-1.00$ & -1.11 & & & \\
\hline sep-00 & -1.05 & -1.43 & -1.26 & -0.96 & -2.58 & -1.58 & $\mid-1.70$ & -1.79 & & & \\
\hline oct-00 & -1.05 & -0.81 & -0.89 & -0.33 & 0.15 & -0.28 & 0.68 & -0.36 & & & \\
\hline nov-00 & -1.06 & \begin{tabular}{|l|} 
\\
\end{tabular} & \begin{tabular}{|c|}
-0.82 \\
\end{tabular} & -0.51 & \begin{tabular}{|l|}
0.26 \\
\end{tabular} & -0.23 & 0.36 & 0.23 & & & \\
\hline dec-00 & -0.63 & -0.70 & -0.53 & 0.07 & 1.29 & 0.24 & 0.61 & 0.67 & & & \\
\hline jan-01 & -0.19 & -0.56 & -0.24 & 0.43 & 0.62 & 0.65 & 0.55 & 0.59 & & & \\
\hline feb-01 & 0.17 & -0.44 & 0.11 & 0.59 & 0.71 & 0.51 & \begin{tabular}{|l|}
0.53 \\
\end{tabular} & 0.59 & & & \\
\hline mar-01 & 0.43 & -0.60 & 0.26 & 1.04 & 0.50 & 0.04 & 0.17 & 0.47 & & & \\
\hline apr-01 & 0.63 & -0.58 & -0.06 & 0.29 & -0.10 & -0.55 & $|-0.25|$ & 0.22 & & & \\
\hline may-01 & 0.53 & -0.38 & -0.02 & 0.38 & 0.07 & -0.35 & -0.05 & 0.00 & & & \\
\hline jun-01 & 0.10 & -0.48 & -0.07 & -0.07 & -0.58 & -0.65 & -0.99 & -0.38 & & & \\
\hline jul-01 & -0.18 & -0.60 & -0.06 & -0.50 & -0.51 & -0.32 & -1.19 & -0.61 & & & \\
\hline aug-01 & -0.21 & -0.58 & 0.03 & -0.55 & \begin{tabular}{|l|}
-1.24 \\
\end{tabular} & $|-0.21|$ & \begin{tabular}{|l|}
-0.53 \\
\end{tabular} & -1.02 & & & \\
\hline sep-01 & -0.19 & -0.56 & 0.44 & -0.47 & 0.21 & -0.02 & 0.45 & -0.39 & & & \\
\hline oct-01 & -0.26 & -0.65 & 0.08 & -0.20 & \begin{tabular}{|l|}
0.38 \\
\end{tabular} & -0.17 & -0.09 & -0.01 & & & \\
\hline nov-01 & -0.28 & -0.57 & 0.11 & -0.26 & \begin{tabular}{|l|}
0.39 \\
\end{tabular} & 0.06 & \begin{tabular}{|l|}
0.19 \\
\end{tabular} & 0.22 & & & \\
\hline
\end{tabular}




\begin{tabular}{|c|c|c|c|c|c|c|c|c|c|c|c|}
\hline Month & $\underline{\underline{\underline{n}}}$ & $\frac{\mathbb{N}}{\frac{1}{0}}$ & $\frac{7}{\frac{7}{d}}$ & $\frac{\varphi}{i} \frac{1}{i}$ & $\frac{m}{\hat{q}}$ & $\begin{array}{l}\overline{0} \\
\alpha_{0}\end{array}$ & $\underline{I}$ & $\stackrel{m}{\stackrel{m}{=}}$ & $\underset{\underline{z}}{\underline{s}}$ & $\sum_{i=1}^{m}$ & 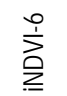 \\
\hline dec-01 & -0.81 & -0.47 & -0.03 & 0.17 & 0.23 & 0.31 & 0.52 & 0.29 & & & \\
\hline jan-02 & -0.80 & -0.46 & -0.28 & 0.23 & 0.22 & 0.14 & 0.25 & 0.36 & & & \\
\hline feb-02 & -0.96 & -0.40 & -0.59 & -0.14 & -0.38 & -0.67 & -0.95 & \begin{tabular}{|l|} 
\\
\end{tabular} & & & \\
\hline mar-02 & -0.90 & -0.21 & -0.38 & -0.10 & -0.27 & -0.43 & -0.60 & $|-0.43|$ & & & \\
\hline apr-02 & -0.89 & -0.15 & $-0.01 \mid$ & 0.27 & 0.37 & 0.00 & -0.14 & \begin{tabular}{|l|}
-0.63 \\
\end{tabular} & & & \\
\hline may-02 & -0.54 & 0.04 & 0.29 & 0.61 & 1.20 & 0.81 & \begin{tabular}{|l|}
0.54 \\
\end{tabular} & -0.20 & & & \\
\hline jun-02 & -0.48 & 0.18 & 0.53 & 0.74 & 1.29 & 0.73 & \begin{tabular}{|l|}
0.56 \\
\end{tabular} & 0.25 & & & \\
\hline jul-02 & -0.48 & 0.29 & 0.66 & 0.95 & 1.19 & 0.34 & 1.13 & 0.74 & -0.49 & & \\
\hline aug-02 & -0.70 & 0.51 & 0.87 & 1.54 & 1.16 & 0.06 & 1.78 & $\mid 1.27$ & 0.39 & & \\
\hline sep-02 & -0.69 & 0.69 & 0.80 & 1.53 & 0.90 & -0.14 & 0.25 & 1.34 & 0.40 & 0.09 & \\
\hline oct-02 & -0.70 & 0.43 & 0.75 & 1.19 & 0.44 & -0.32 & $-0.20 \mid$ & 0.62 & 0.30 & 0.39 & \\
\hline nov-02 & -0.28 & 0.48 & 0.77 & 0.62 & -0.05 & \begin{tabular}{|l|} 
\\
\end{tabular} & \begin{tabular}{|l|}
-0.01 \\
\end{tabular} & \begin{tabular}{|l|} 
\\
\end{tabular} & \begin{tabular}{|c|}
-1.29 \\
\end{tabular} & -0.21 & \\
\hline dec-02 & -0.11 & 0.44 & 0.84 & 0.63 & 0.15 & -0.07 & \begin{tabular}{|l|}
-0.04 \\
\end{tabular} & \begin{tabular}{|l|}
-0.09 \\
\end{tabular} & 0.17 & -0.26 & 0.1 \\
\hline jan-03 & 0.06 & 0.35 & 0.92 & 0.41 & 0.40 & 0.13 & 0.11 & 0.04 & 0.24 & $-0.24 \mid$ & 0.10 \\
\hline feb-03 & 0.21 & 0.55 & 1.40 & 0.44 & 0.80 & 0.98 & 1.06 & 0.43 & -0.18 & 0.10 & -0.09 \\
\hline mar-03 & 0.35 & 0.49 & 1.23 & 0.55 & 0.74 & 0.94 & 0.75 & 0.70 & -0.68 & -0.32 & -0.32 \\
\hline apr-03 & 0.59 & 0.60 & 1.01 & 0.64 & 0.81 & 0.93 & 0.89 & 0.96 & 0.84 & -0.08 & -0.18 \\
\hline may-03 & 0.70 & 0.62 & 0.77 & 0.72 & 0.56 & 1.24 & \begin{tabular}{|l|}
0.93 \\
\end{tabular} & \begin{tabular}{|l|l|}
0.90 \\
\end{tabular} & 0.65 & 0.34 & 0.25 \\
\hline jun-03 & 0.58 & 0.72 & 0.73 & 0.74 & 0.55 & $\begin{array}{ll}1.02 \\
\end{array}$ & \begin{tabular}{|l|}
0.36 \\
\end{tabular} & \begin{tabular}{|l|}
0.90 \\
\end{tabular} & 0.32 & 0.66 & 0.27 \\
\hline jul-03 & 0.29 & 0.70 & 0.59 & 0.70 & 0.37 & 1.14 & -0.34 & \begin{tabular}{|l|}
0.63 \\
\end{tabular} & -0.66 & 0.21 & 0.10 \\
\hline aug-03 & 0.05 & 0.77 & 0.44 & 0.44 & 0.18 & 0.99 & 0.42 & 0.25 & -0.24 & -0.12 & 0.10 \\
\hline sep-03 & 0.13 & 0.77 & 0.58 & 0.53 & 0.32 & 1.02 & 0.28 & 0.24 & -0.10 & -0.36 & 0.22 \\
\hline oct-03 & 0.35 & 0.99 & 0.94 & 1.07 & 1.16 & 1.88 & 1.25 & 1.47 & 0.64 & 0.07 & 0.13 \\
\hline nov-03 & 0.50 & 1.00 & 0.91 & 0.69 & 0.76 & 1.68 & 0.65 & 1.09 & -0.57 & 0.01 & -0.15 \\
\hline dec-03 & 0.45 & 0.93 & 0.77 & 0.51 & 0.59 & 1.05 & 0.05 & \begin{tabular}{|l|}
0.76 \\
\end{tabular} & 1.17 & 0.83 & 0.07 \\
\hline jan-04 & 0.06 & 0.85 & 0.55 & 0.18 & -0.82 & $\mid 0.21$ & -0.67 & \begin{tabular}{|l|}
-0.07 \\
\end{tabular} & 0.82 & 0.66 & 0.48 \\
\hline feb-04 & -0.15 & 1.09 & 0.42 & 0.31 & -0.30 & 0.48 & \begin{tabular}{|l|}
-0.12 \\
\end{tabular} & $\mid-0.30$ & 1.06 & 1.28 & 0.84 \\
\hline mar-04 & 0.06 & 1.16 & 0.79 & 0.81 & 0.77 & 1.51 & 0.81 & 0.01 & 1.09 & 1.16 & 1.07 \\
\hline apr-04 & 0.31 & 1.19 & 0.93 & 0.62 & 1.55 & 2.25 & 1.52 & 0.69 & 2.76 & 1.85 & 1.47 \\
\hline may-04 & 0.70 & 1.13 & 1.01 & 0.96 & 1.58 & 3.40 & 2.18 & 1.45 & 0.80 & 1.73 & 1.68 \\
\hline jun-04 & 0.89 & 1.08 & 1.06 & 1.27 & 1.34 & 3.00 & 1.12 & $\mid 1.89$ & 1.16 & 1.61 & 1.58 \\
\hline jul-04 & 0.90 & 1.06 & 1.17 & 1.72 & 1.16 & 2.35 & 1.50 & | 2.01 & 0.50 & 0.95 & 1.49 \\
\hline aug-04 & 0.63 & 0.87 & 1.00 & 1.45 & 0.10 & 2.23 & -0.22 & 0.87 & 0.36 & 0.78 & 1.35 \\
\hline sep-04 & 0.59 & 0.95 & 1.06 & 1.17 & 0.10 & 1.83 & -0.11 & \begin{tabular}{|l|}
0.32 \\
\end{tabular} & 0.92 & 0.64 & 1.24 \\
\hline oct-04 & 0.53 & 0.94 & 0.67 & 0.52 & -0.66 & 1.06 & -0.49 & $|-0.50|$ & -0.81 & 0.14 & 0.61 \\
\hline nov-04 & 0.41 & 0.76 & 0.40 & -1.01 & -0.87 & 0.32 & -1.19 & \begin{tabular}{|l|}
-0.93 \\
\end{tabular} & -1.52 & -0.66 & 0.25 \\
\hline dec-04 & 0.12 & 0.90 & 0.80 & -0.47 & -0.56 & $|0.61|$ & -0.53 & $|-0.95|$ & -0.09 & $|-1.11|$ & -0.13 \\
\hline jan-05 & -0.02 & 0.76 & 0.78 & -1.12 & -0.68 & -0.07 & -0.90 & $|-1.03|$ & -1.36 & $|-1.00|$ & -0.56 \\
\hline feb-05 & -0.19 & 0.55 & 0.61 & -0.87 & 0.11 & 0.13 & -0.45 & $|-0.68|$ & -2.62 & $|-1.60|$ & -1.47 \\
\hline mar-05 & -0.33 & 0.41 & 0.03 & -1.25 & -1.37 & $|-0.47|$ & -0.67 & $|-0.71|$ & -2.11 & -2.45 & -2.00 \\
\hline apr-05 & -0.57 & 0.25 & -0.54 & -1.00 & $\mid-0.85$ & -1.17 & -0.88 & $\mid-0.66$ & -2.27 & -2.73 & -2.19 \\
\hline may-05 & -0.91 & -0.12 & -1.31 & -0.90 & $-1.67 \mid$ & -2.42 & -1.26 & -0.93 & -1.73 & $|-2.49|$ & -2.30 \\
\hline jun-05 & -1.00 & -0.05 & -1.29 & -1.67 & -1.20 & -2.24 & -0.65 & $|-1.11|$ & -1.73 & $|-2.15|$ & -2.5 \\
\hline jul-05 & -1.00 & 0.01 & -1.37 & -1.09 & -0.59 & -1.92 & -0.20 & $|-1.04|$ & -1.03 & $-1.75 \mid$ & -2.42 \\
\hline aug-05 & -1.19 & -0.12 & -1.28 & -1.39 & 0.16 & -1.60 & -0.59 & $|-0.60|$ & -1.55 & $-1.53 \mid$ & -2.18 \\
\hline sep-05 & -1.28 & -0.11 & -1.39 & -1.26 & -0.20 & \begin{tabular}{|l|}
-1.48 \\
\end{tabular} & -0.34 & \begin{tabular}{|l|}
-0.53 \\
\end{tabular} & -1.03 & $\mid-1.27$ & -1.84 \\
\hline oct-05 & -1.14 & -0.42 & -1.34 & -1.14 & -0.65 & $\mid-1.75$ & -0.60 & $|-0.82|$ & -0.75 & $\mid-1.39$ & -1.66 \\
\hline nov-05 & -0.98 & -0.43 & -0.96 & -0.18 & -0.06 & -1.31 & 0.06 & -0.26 & 0.46 & -0.91 & -1.43 \\
\hline dec-05 & -1.24 & -0.48 & \begin{tabular}{|c|} 
\\
\end{tabular} & -0.81 & -0.73 & $\mid-1.64$ & $|-0.61|$ & $|-0.45|$ & -1.43 & $\mid-1.10$ & -1.51 \\
\hline
\end{tabular}

\begin{tabular}{|c|c|c|c|c|c|c|c|c|c|c|c|}
\hline Month & पू & $\begin{array}{l}d \\
\frac{d}{2}\end{array}$ & $\frac{7}{\frac{7}{0}}$ & $\frac{\varphi}{\frac{\varphi}{n}}$ & $\frac{m}{\frac{m}{n}}$ & $\begin{array}{l}\bar{\phi} \\
\alpha\end{array}$ & $\underline{\underline{I}}$ & $\stackrel{m}{\underline{m}} \stackrel{0}{=}$ & 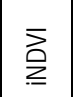 & $\sum_{i=1}^{m}$ & 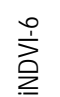 \\
\hline jan-06 & -1.09 & -0.24 & -1.17 & -0.37 & 0.22 & -1.01 & 0.34 & -0.02 & -0.69 & -0.78 & -1.4 \\
\hline feb-06 & -1.12 & -0.39 & \begin{tabular}{|c|}
-1.24 \\
\end{tabular} & -0.33 & -0.03 & -0.96 & 0.41 & 0.12 & -0.43 & $\begin{array}{l}-1.08 \\
\end{array}$ & -1.2 \\
\hline mar-06 & -0.97 & -0.77 & \begin{tabular}{|c|}
-1.08 \\
\end{tabular} & -0.52 & 0.03 & -1.40 & -0.20 & 0.22 & 0.75 & -0.06 & -0.52 \\
\hline apr-06 & -1.16 & -1.04 & -0.89 & -0.22 & -0.55 & -1.68 & -0.37 & 0.00 & -0.37 & 0.05 & -0.40 \\
\hline may-06 & -1.16 & -1.41 & -0.44 & -0.31 & -0.31 & -2.01 & -0.32 & -0.29 & -0.49 & -0.07 & -0.58 \\
\hline jun-06 & -1.23 & -1.25 & -0.40 & 0.04 & 0.19 & -1.70 & 0.22 & -0.28 & -0.87 & -0.70 & -0.48 \\
\hline jul-06 & -1.26 & -1.30 & 0.43 & 0.25 & 0.34 & -1.40 & 0.06 & -0.11 & -0.64 & -0.76 & -0.4 \\
\hline aug-06 & -1.46 & -1.34 & -0.41 & -0.30 & 0.24 & -1.14 & -0.59 & -0.11 & -0.45 & -0.72 & -0.4 \\
\hline sep-06 & -1.46 & -1.26 & -0.36 & -0.08 & -0.18 & -1.10 & -0.12 & -0.33 & -0.29 & -0.49 & -0.6 \\
\hline oct-06 & -1.27 & -1.26 & -0.38 & -0.34 & -0.63 & -1.84 & -0.52 & -0.66 & -1.79 & -1.08 & -0.9 \\
\hline nov-06 & -0.98 & -0.88 & -0.20 & 0.30 & 0.36 & -1.11 & 0.33 & -0.01 & 0.86 & -0.89 & -0.8 \\
\hline dec-06 & -1.14 & -1.33 & -0.27 & -0.43 & -0.22 & -1.67 & -0.49 & -0.25 & \begin{tabular}{|l|l|}
0.28 \\
\end{tabular} & -0.44 & -0.62 \\
\hline jan-07 & -1.13 & -1.26 & -0.59 & -0.37 & 0.21 & -1.70 & -0.40 & \begin{tabular}{l|}
-0.24 \\
\end{tabular} & 0.31 & 0.51 & -0.38 \\
\hline feb-07 & -1.04 & -1.11 & -0.39 & 0.09 & -0.27 & -1.68 & -0.48 & -0.48 & 0.99 & 0.67 & -0.0 \\
\hline mar-07 & -0.97 & -0.80 & 0.00 & 0.15 & 0.48 & -1.05 & -0.02 & -0.30 & -0.73 & 0.13 & -0.1 \\
\hline apr-07 & -0.65 & -0.25 & 0.54 & 0.94 & 1.42 & 0.47 & 1.11 & 0.12 & -1.23 & -0.38 & 0.04 \\
\hline may-07 & -0.58 & -0.19 & 0.37 & 0.41 & 0.90 & -0.10 & 0.02 & 0.38 & 0.55 & -0.39 & 0.05 \\
\hline jun-07 & -0.61 & -0.26 & 0.20 & 0.63 & 0.64 & -0.22 & -0.45 & 0.50 & 0.19 & 0.00 & 0.07 \\
\hline jul-07 & -0.66 & -0.33 & 0.13 & 0.63 & -1.14 & 0.10 & -1.04 & -0.35 & -0.43 & 0.18 & -0.06 \\
\hline aug-07 & -0.88 & -0.25 & 0.26 & 0.62 & -0.25 & 0.11 & 0.01 & -0.50 & -0.24 & -0.11 & -0.27 \\
\hline sep-07 & -0.92 & -0.19 & 0.26 & 0.37 & -0.11 & -0.07 & -0.25 & -0.47 & -0.70 & -0.49 & -0.22 \\
\hline oct-07 & -0.79 & 0.18 & 0.77 & 0.17 & 1.06 & 1.00 & 0.69 & 0.60 & 1.15 & 0.03 & 0.0 \\
\hline nov-07 & -0.85 & -0.08 & 0.26 & 0.00 & 0.31 & 0.34 & -0.55 & -0.02 & -0.64 & -0.08 & -0.1 \\
\hline dec-07 & -1.05 & -0.05 & 0.35 & -0.16 & 0.07 & -0.26 & -1.08 & -0.50 & -0.21 & 0.23 & -0.31 \\
\hline jan-08 & -0.97 & -0.30 & 0.27 & -0.15 & -1.33 & -0.75 & -1.12 & -1.10 & -0.37 & -0.43 & -0.26 \\
\hline feb-08 & -1.00 & -0.13 & 0.32 & -0.05 & -0.14 & -0.78 & -0.90 & -1.10 & 0.99 & 0.20 & 0.05 \\
\hline mar-08 & -1.05 & -0.19 & -0.08 & -0.39 & -0.57 & -1.66 & -1.12 & -1.11 & 0.88 & 0.66 & 0.49 \\
\hline apr-08 & -0.93 & -0.10 & -0.62 & -0.77 & 0.03 & -1.59 & -0.66 & -0.95 & -0.21 & 0.70 & 0.18 \\
\hline may-08 & 0.66 & 0.21 & 0.14 & 0.30 & 0.69 & -0.17 & 0.66 & -0.60 & -0.60 & -0.03 & 0.0 \\
\hline jun-08 & -0.12 & 0.42 & 0.62 & 1.03 & 1.75 & 0.38 & 2.19 & 0.38 & 1.13 & 0.18 & 0.4 \\
\hline jul-08 & 0.04 & 0.41 & 0.67 & 1.25 & 1.73 & 0.13 & 1.30 & 1.43 & 1.47 & 0.62 & 0.73 \\
\hline aug-08 & -0.08 & 0.41 & 0.55 & 1.03 & 1.02 & 0.26 & -0.28 & 1.32 & 1.04 & 1.24 & 0.72 \\
\hline sep-08 & -0.01 & 0.50 & 0.69 & 1.56 & 0.02 & 0.34 & 0.18 & 0.40 & 0.39 & 1.03 & 0.59 \\
\hline oct-08 & 0.22 & 1.12 & 1.11 & 2.64 & 1.82 & 3.03 & 2.68 & 2.50 & 0.04 & 0.53 & 0.56 \\
\hline nov-08 & 0.59 & 0.92 & 1.25 & 1.81 & 1.37 & 2.76 & 1.85 & 2.48 & 1.35 & 0.81 & 1.08 \\
\hline dec-08 & 0.40 & 1.09 & 1.44 & 1.33 & 1.81 & 2.62 & 1.99 & 2.66 & 1.01 & 1.19 & 1.26 \\
\hline jan-09 & 0.35 & 1.31 & 1.79 & 1.31 & 0.28 & 3.01 & 1.83 & 2.19 & 2.16 & 1.66 & 1.4 \\
\hline feb-09 & 0.41 & 1.17 & 1.60 & 1.37 & 0.36 & 2.59 & 1.66 & 1.92 & 0.82 & 1.57 & 1.43 \\
\hline mar-09 & 0.43 & 1.18 & 1.91 & 1.62 & 0.90 & 3.14 & 1.59 & 1.84 & 0.91 & 1.42 & 1.38 \\
\hline apr-09 & 0.43 & 0.77 & 1.63 & 0.22 & 0.22 & 2.55 & 0.98 & 1.55 & -0.01 & 0.72 & 1.33 \\
\hline may-09 & 0.12 & 0.67 & 0.96 & 0.06 & -0.09 & 1.43 & -0.18 & 1.07 & 0.66 & 0.71 & 1.21 \\
\hline jun-09 & 0.01 & 0.62 & 0.51 & -0.22 & -1.77 & 0.96 & -0.99 & 0.23 & -0.14 & 0.23 & 0.82 \\
\hline jul-09 & 0.04 & 0.62 & 0.46 & -0.75 & -1.81 & 1.23 & -1.18 & -0.69 & -0.38 & 0.10 & 0.40 \\
\hline aug-09 & $0 \Omega 3$ & 0.56 & 0.49 & -0.72 & -1.23 & 1.21 & -0.64 & -1.05 & -0.32 & -0.27 & 0.2 \\
\hline sep-09 & 0.27 & 0.92 & 0.91 & -0.33 & 1.11 & 2.18 & 1.57 & 0.18 & -0.46 & -0.41 & -0.0 \\
\hline oct-09 & 0.27 & 0.57 & -0.13 & -0.56 & 0.61 & 0.95 & -0.56 & -0.02 & 0.61 & -0.12 & -0.0 \\
\hline nov-09 & 0.15 & 0.56 & -0.39 & -0.63 & 0.08 & -0.03 & -1.44 & -0.77 & -1.03 & -0.43 & -0.4 \\
\hline dec-00 & 0.54 & 1.15 & 0.46 & 1.13 & 0.66 & 2.35 & 1.16 & -0.35 & -2.29 & -1.50 & -1.07 \\
\hline jan-10 & 0.97 & 1.55 & 0.68 & 1.45 & 1.47 & 3.28 & 1.80 & 0.74 & -1.49 & -1.93 & -1.34 \\
\hline
\end{tabular}




\begin{tabular}{|c|c|c|c|c|c|c|c|c|c|c|c|}
\hline Month & $\underline{\bar{n}}$ & 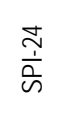 & $\frac{7}{\frac{7}{a}}$ & $\frac{\varphi}{\frac{\varphi}{\omega}}$ & $\frac{m}{\frac{m}{n}}$ & $\begin{array}{l}\overline{0} \\
0\end{array}$ & $\stackrel{I}{\underline{I}}$ & $\stackrel{m}{\underline{\underline{I}}}$ & 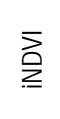 & $\sum_{n}^{m}$ & $\sum_{\underline{1}}^{\varphi}$ \\
\hline
\end{tabular}

\begin{tabular}{|l|l|l|l|l|l|l|l|l|l|l|l|}
\hline feb-10 & 1.30 & 1.62 & 1.11 & 1.94 & 2.03 & 4.08 & 2.53 & 2.00 & 0.28 & -1.46 & -1.27 \\
\hline
\end{tabular} \begin{tabular}{|l|l|l|l|l|l|l|l|l|l|l|l|}
\hline mar-10 & 1.37 & 1.77 & 1.02 & 1.65 & 1.73 & 4.56 & 2.76 & 2.54 & -0.86 & -0.78 & -1.14 \\
\hline
\end{tabular} \begin{tabular}{|c|c|c|c|c|c|c|c|c|c|c|c|}
\hline apr-10 & 1.50 & 1.78 & 1.19 & 1.65 & 1.41 & 4.50 & 2.43 & 2.73 & 0.39 & -0.14 & -1.13 \\
\hline
\end{tabular} \begin{tabular}{|c|c|c|c|c|c|c|c|c|c|c|c|}
\hline may-10 & 1.48 & 1.42 & 1.21 & 1.68 & 0.71 & 4.25 & 1.50 & 2.54 & 0.57 & 0.08 & -0.67 \\
\hline
\end{tabular} \begin{tabular}{|c|c|c|c|c|c|c|c|c|c|c|c|}
\hline jun-10 & 1.55 & 1.32 & 1.58 & 1.61 & 0.88 & 4.22 & 2.04 & 2.32 & 1.21 & 0.90 & 0.21 \\
\hline
\end{tabular} \begin{tabular}{|c|c|c|c|c|c|c|c|c|c|c|c|}
\hline jul-10 & 1.59 & 1.29 & 1.59 & 1.36 & 0.73 & 3.71 & 1.15 & 1.86 & 1.82 & 1.24 & 0.75 \\
\hline
\end{tabular} \begin{tabular}{|l|l|l|l|l|l|l|l|l|l|l|l|l|}
\hline aug-10 & 1.70 & 1.41 & 1.64 & 1.07 & 1.07 & 3.14 & 0.99 & 1.69 & 1.60 & 1.54 & 0.95 \\
\hline
\end{tabular} \begin{tabular}{|l|l|l|l|l|l|l|l|l|l|l|l|l|}
\hline sep-10 & 1.63 & 1.40 & 1.40 & 0.84 & 0.34 & 2.70 & 0.13 & 0.91 & 1.85 & 1.87 & 1.40 \\
\hline
\end{tabular} \begin{tabular}{|c|c|c|c|c|c|c|c|c|c|c|c|}
\hline oct-10 & 1.54 & 0.96 & 1.59 & 0.68 & 0.32 & 2.52 & -0.05 & 0.43 & 1.18 & 1.82 & 1.46 \\
\hline
\end{tabular} \begin{tabular}{|c|c|c|c|c|c|c|c|c|c|c|c|}
\hline nov-10 & 1.58 & 1.01 & 1.79 & 0.55 & -0.02 & 2.36 & 0.05 & 0.09 & 0.59 & 2.03 & 1.69 \\
\hline
\end{tabular} \begin{tabular}{|l|l|l|l|l|l|l|l|l|l|l|l|}
\hline dec-10 & 1.57 & 1.24 & 1.57 & 0.60 & 0.69 & 3.35 & 1.24 & 0.55 & 0.87 & 1.41 & 1.97 \\
\hline
\end{tabular} \begin{tabular}{|c|c|c|c|c|c|c|c|c|c|c|c|}
\hline jan-11 & 1.34 & 1.15 & 1.23 & 0.36 & 0.42 & 2.81 & 0.63 & 0.73 & 0.74 & 0.86 & 1.77 \\
\hline
\end{tabular} \begin{tabular}{|l|l|l|l|l|l|l|l|l|l|l|l|}
\hline feb-11 & 1.26 & 1.08 & 0.75 & 0.04 & 0.36 & 2.31 & 0.32 & 0.72 & 0.03 & 0.69 & 1.40 \\
\hline
\end{tabular} \begin{tabular}{|c|c|c|c|c|c|c|c|c|c|c|c|}
\hline mar-11 & 1.11 & 1.01 & 0.78 & 0.52 & 0.28 & 2.86 & 0.91 & 0.68 & 0.77 & 0.59 & 0.97 \\
\hline
\end{tabular} \begin{tabular}{|c|c|c|c|c|c|c|c|c|c|c|c|}
\hline apr-11 & 1.06 & 1.16 & 0.70 & 0.59 & 0.70 & 2.48 & 0.46 & 0.62 & 0.61 & 0.57 & 0.81 \\
\hline
\end{tabular} \begin{tabular}{|c|c|c|c|c|c|c|c|c|c|c|c|}
\hline may-11 & 1.15 & 1.30 & 0.78 & 0.77 & 1.00 & 2.50 & 0.58 & 0.75 & 1.58 & 1.35 & 1.16 \\
\hline ju-11 & 1.24 & 1.33 & 0.53 & 0.46 & 0.55 & 2.10 & -0.12 & 0.43 & 0.76 & 1.21 & 1.06 \\
\hline
\end{tabular} \begin{tabular}{|l|l|l|l|l|l|l|l|l|l|l|l|}
\hline jun-11 & 1.24 & 1.33 & 0.53 & 0.46 & 0.55 & 2.10 & -0.12 & 0.43 & 0.76 & 1.21 & 1.06 \\
\hline
\end{tabular} \begin{tabular}{|c|c|c|c|c|c|c|c|c|c|c|c|}
\hline jul-11 & 1.46 & 1.32 & 0.50 & 0.61 & 0.35 & 2.03 & -0.39 & 0.24 & 1.29 & 1.33 & 1.14 \\
\hline
\end{tabular} \begin{tabular}{|l|l|l|l|l|l|l|l|l|l|l|l|l|}
\hline aug-11 & 1.56 & 1.30 & 0.30 & 0.57 & -0.86 & 1.99 & -0.82 & -0.48 & 0.42 & 0.85 & 1.19 \\
\hline
\end{tabular} \begin{tabular}{|l|l|l|l|l|l|l|l|l|l|l|l|}
\hline sep-11 & 1.59 & 0.95 & 0.14 & -0.35 & -1.75 & 1.25 & -1.42 & -1.29 & 0.11 & 0.66 & 1.02 \\
\hline
\end{tabular} \begin{tabular}{|c|c|c|c|c|c|c|c|c|c|c|c|}
\hline oct-11 & 1.50 & 1.01 & -0.04 & -1.15 & -2.05 & 0.29 & -0.98 & -1.69 & -1.05 & -0.28 & 0.68 \\
\hline
\end{tabular} \begin{tabular}{|c|c|c|c|c|c|c|c|c|c|c|c|}
\hline nov-11 & 1.37 & 1.44 & 0.43 & -0.39 & 0.18 & 1.39 & 0.81 & -0.19 & 0.67 & -0.31 & 0.42 \\
\hline
\end{tabular} \begin{tabular}{|l|l|l|l|l|l|l|l|l|l|l|l|}
\hline dec-11 & 1.15 & 0.88 & -0.21 & -1.04 & -0.05 & 0.34 & -0.52 & -0.19 & 0.59 & 0.07 & 0.45 \\
\hline
\end{tabular} \begin{tabular}{|c|c|c|c|c|c|c|c|c|c|c|c|}
\hline jan-12 & 0.97 & 0.62 & -0.21 & -0.88 & 0.34 & 0.03 & -0.51 & -0.14 & 0.55 & 0.69 & 0.26 \\
\hline
\end{tabular} \begin{tabular}{|l|l|l|l|l|l|l|l|l|l|l|l|}
\hline feb-12 & 0.77 & 0.16 & -0.40 & -1.17 & -1.98 & -0.31 & -0.74 & -0.63 & -0.32 & 0.34 & 0.04 \\
\hline
\end{tabular}

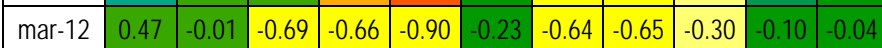
\begin{tabular}{|l|l|l|l|l|l|l|l|l|l|l|l|}
\hline apr-12 & 0.39 & -0.07 & -0.78 & -0.09 & -0.45 & -0.08 & -0.41 & -0.63 & 0.45 & -0.10 & 0.31 \\
\hline
\end{tabular} \begin{tabular}{|l|l|l|l|l|l|l|l|l|l|l|l|}
\hline may-12 & 0.29 & -0.29 & -1.22 & -1.27 & -0.38 & -1.24 & -1.02 & -0.69 & -0.67 & -0.34 & -0.04 \\
\hline
\end{tabular} \begin{tabular}{|l|l|l|l|l|l|l|l|l|l|l|l|}
\hline jun-12 & 0.36 & -0.54 & -1.33 & -1.19 & -0.89 & -1.39 & -1.21 & -0.89 & -0.42 & -0.37 & -0.29 \\
\hline
\end{tabular} \begin{tabular}{|lll|l|l|l|l|l|l|l|l|l|}
\hline jul-12 & 0.42 & -0.53 & -1.31 & -1.27 & -1.51 & -1.03 & -1.02 & -1.25 & -1.05 & -0.77 & -0.55 \\
\hline
\end{tabular} \begin{tabular}{|l|l|l|l|l|l|l|l|l|l|l|l|l|}
\hline aug-12 & 0.41 & -0.72 & -1.22 & -0.92 & -0.88 & -0.71 & -0.91 & -1.22 & -1.25 & -0.86 & -0.68 \\
\hline
\end{tabular} \begin{tabular}{|l|l|l|l|l|l|l|l|l|l|l|l|}
\hline sep-12 & 0.45 & -0.46 & -0.66 & -0.51 & 0.44 & -0.21 & 0.76 & -0.34 & -1.27 & -1.26 & -0.80 \\
\hline
\end{tabular} \begin{tabular}{|c|c|c|c|c|c|c|c|c|c|c|c|}
\hline oct-12 & 0.53 & -0.29 & -0.17 & -0.12 & 0.92 & 0.54 & 0.74 & 0.75 & 0.92 & -0.69 & -0.77 \\
\hline
\end{tabular} \begin{tabular}{|c|c|c|c|c|c|c|c|c|c|c|c|}
\hline nov-12 & 0.93 & 0.09 & -0.12 & 1.27 & 1.52 & 1.92 & 1.96 & 1.77 & 1.26 & 0.29 & -0.56 \\
\hline
\end{tabular} \begin{tabular}{|c|c|c|c|c|c|c|c|c|c|c|c|}
\hline dec-12 & 0.78 & -0.33 & -0.12 & 1.10 & 1.26 & 0.93 & 0.69 & 1.47 & 0.93 & 1.58 & -0.23 \\
\hline
\end{tabular} \begin{tabular}{|c|c|c|c|c|c|c|c|c|c|c|c|}
\hline jan-13 & 0.76 & -0.31 & -0.08 & 0.93 & 0.67 & 0.84 & 0.31 & 1.07 & 0.60 & 1.05 & 0.22 \\
\hline
\end{tabular} \begin{tabular}{|c|c|c|c|c|c|c|c|c|c|c|c|c|}
\hline feb-13 & 0.69 & -0.13 & 0.34 & 1.20 & -0.25 & 1.03 & 0.68 & 0.57 & 0.27 & 0.76 & 0.61 \\
\hline
\end{tabular} \begin{tabular}{|c|c|c|c|c|c|c|c|c|c|c|c|}
\hline mar-13 & 1.07 & 0.14 & 0.97 & 1.68 & 1.43 & 3.06 & 1.42 & 0.87 & 0.78 & 0.64 & 1.07 \\
\hline
\end{tabular} \begin{tabular}{|c|c|c|c|c|c|c|c|c|c|c|c|c|}
\hline apr-13 & 1.54 & 0.31 & 1.17 & 1.49 & 1.88 & 3.62 & 1.93 & 1.35 & 1.11 & 0.84 & 1.07 \\
\hline
\end{tabular} \begin{tabular}{|c|c|c|c|c|c|c|c|c|c|c|c|c|}
\hline may-13 & 1.73 & 0.08 & 1.16 & 0.82 & 1.39 & 3.24 & 1.06 & 1.61 & 0.70 & 1.04 & 1.01 \\
\hline jun 13 & 1.60 & 0.06 & 1.21 & 1.13 & 0.40 & 2.81 & -0.01 & 1.43 & 0.89 & 1.01 & 0.95 \\
\hline
\end{tabular} \begin{tabular}{|l|l|l|l|l|l|l|l|l|l|l|l|l|}
\hline jun-13 & 1.60 & 0.06 & 1.21 & 1.13 & 0.40 & 2.81 & -0.01 & 1.43 & 0.89 & 1.01 & 0.95 \\
\hline
\end{tabular} \begin{tabular}{|c|c|c|c|c|c|c|c|c|c|c|c|c|}
\hline jul-13 & 1.50 & 0.12 & 1.26 & 1.31 & -0.36 & 2.46 & 0.50 & 0.74 & 0.42 & 0.77 & 0.89 \\
\hline
\end{tabular} \begin{tabular}{|l|l|l|l|l|l|l|l|l|l|l|l|}
\hline aug-13 & 1.65 & 0.37 & 1.49 & 1.53 & 0.81 & 1.84 & 1.88 & 0.86 & 1.40 & 0.91 & 1.07 \\
\hline
\end{tabular} \begin{tabular}{|l|l|l|l|l|l|l|l|l|l|l|l|}
\hline sep-13 & 1.68 & 0.43 & 1.28 & 0.53 & 0.52 & 1.13 & -0.56 & 0.74 & 1.81 & 1.27 & 1.18 \\
\hline
\end{tabular} \begin{tabular}{|c|c|c|c|c|c|c|c|c|c|c|c|}
\hline oct-13 & 1.23 & 0.37 & 0.87 & -1.01 & -0.72 & -0.33 & -1.16 & -0.56 & 0.95 & 1.63 & 1.10 \\
\hline
\end{tabular} \begin{tabular}{|l|l|l|l|l|l|l|l|l|l|l|l|}
\hline nov-13 & 1.37 & -0.14 & 0.11 & -1.37 & -2.41 & -0.93 & -1.53 & -1.55 & -0.14 & 1.54 & 1.09 \\
\hline
\end{tabular} \begin{tabular}{|l|l|l|l|l|l|l|l|l|l|l|l|}
\hline dec-13 & 1.15 & 0.03 & 0.34 & -1.33 & -2.72 & -1.07 & -1.57 & -1.81 & -0.43 & 0.19 & 0.96 \\
\hline
\end{tabular} \begin{tabular}{|l|l|l|l|l|l|l|l|l|l|l|l|}
\hline jan-14 & 1.17 & 0.07 & 0.37 & -1.09 & -0.58 & -1.08 & -0.99 & -1.54 & -0.20 & -0.32 & 0.88 \\
\hline
\end{tabular} \begin{tabular}{|l|l|l|l|l|l|l|l|l|l|l|l|}
\hline feb-14 & 1.22 & 0.33 & 0.35 & -1.63 & 0.27 & -0.95 & -0.60 & -1.07 & 0.18 & -0.18 & 0.56 \\
\hline
\end{tabular}

\begin{tabular}{|c|c|c|c|c|c|c|c|c|c|c|c|}
\hline Month & Ф̄ & $\frac{\stackrel{d}{\Delta}}{\frac{i}{n}}$ & $\frac{7}{\frac{1}{n}}$ & $\frac{\varphi}{\frac{\varphi}{n}}$ & $\frac{m}{\frac{m}{n}}$ & $\begin{array}{l}\overline{0} \\
0\end{array}$ & $\stackrel{I}{\underline{I}}$ & $\stackrel{m}{\stackrel{m}{I}}$ & 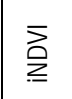 & 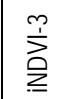 & $\sum_{\underline{\underline{q}}}^{\underline{\varphi}}$ \\
\hline mar-14 & 1.22 & 0.27 & -0.44 & \begin{tabular}{|l|}
-1.22 \\
\end{tabular} & 0.22 & $\mid-1.27$ & -0.40 & -0.70 & 0.59 & 0.26 & 0.23 \\
\hline apr-14 & 1.22 & 0.08 & -1.24 & -0.70 & -0.44 & -2.34 & -0.77 & -0.59 & 0.68 & 0.57 & $\mid 0.17$ \\
\hline may-14 & 0.82 & 0.02 & -1.33 & -0.71 & -1.52 & -3.29 & -1.28 & -0.76 & -1.22 & -0.20 & -0.21 \\
\hline jun-14 & 0.41 & 0.16 & -1.11 & -0.64 & -1.31 & -2.95 & -0.41 & -1.01 & -1.35 & -0.97 & -0.50 \\
\hline jul-14 & 0.81 & 0.21 & -1.12 & -0.70 & -0.43 & -2.71 & 0.12 & -0.90 & -0.31 & -1.17 & -0.50 \\
\hline aug-14 & 0.85 & 0.19 & -1.65 & -1.22 & 0.23 & -2.26 & -0.75 & -0.46 & -0.81 & -0.93 & -0.65 \\
\hline sep-14 & 0.95 & 0.08 & -1.41 & -1.33 & $\mid-0.19$ & -2.18 & -0.30 & -0.48 & -0.72 & -0.64 & -0.86 \\
\hline oct-14 & 0.88 & -0.27 & -1.37 & \begin{tabular}{|l|}
-1.69 \\
\end{tabular} & -1.56 & -3.38 & -1.08 & -1.30 & -0.73 & -0.97 & -1.14 \\
\hline nov-14 & 0.93 & -0.33 & -0.43 & 0.40 & 0.46 & -1.75 & 0.85 & 0.02 & -0.58 & -1.18 & -1.11 \\
\hline dec-14 & 0.87 & -0.24 & -0.57 & -0.06 & 0.26 & -1.93 & 0.36 & 0.18 & 0.60 & -0.26 & -0.65 \\
\hline
\end{tabular}

Table 3. Evolution of drought indicators in the Júcar system 


\section{Discussion}

Correlations between indices, iSI, SPI-24 SPI-12 SPI-6, SPI-3, PDSI, iHI, iHI-3, iNDVI, iNDVI-3 and iNDVI6 , are analysed for the two larger water resources systems, Turia and Júcar, of the Júcar RBD, (Table 4). In both systems, the same structure about what are the better correlations is produced (see bold numbers in table 4). The operational drought index iSI is better correlated with SPI-24 and the PDSI with SPI-12. In the case of moisture indices, $\mathrm{iHI}$ it is more similar to the short-term meteorological index SPI-3 and then iHI-6 is better correlated with SPI-6. For the vegetation indices, iNDVI, iNDVI-3 iNDVI-6 are better correlated with SPI-12 and PDSI, in both cases with similar values.

In both systems the operational drought index, iSI, is better correlated with the long-term meteorological index SPI-24, 0.81 for the Turia system and 0.62 for the Júcar system. The correlation in the Júcar system is lower due to the larger size of this water resources system. Different behaviours can be produced at the same time in a large basin during a drought, as has been shown previously, the upper basin could be under wet conditions and the rest of the basin under drought conditions, and the contrary is also possible. Then long-term meteorological index could be used in small or medium size basins to the definition of the concept of "prolonged drought". However, in the case of large basins, the spatial distribution of the drought indices must be included.

PDSI has a moderate correlation with the operational index iSI (0.72 Turia and 0.57 Júcar) that is lower than the long-term meteorological index SPI-24. PDSI and SPI-12 have the better correlation with the vegetative indices. The PDSI complements the monitoring of the agricultural drought in the entire River Basin District. If the drought condition remains at different time scales, impacts on all components of the hydrological cycle may take place. PSDI presents, moreover, better relation to the pattern of long term precipitation (SPI-12) and is considered, therefore, an indicator of the moisture content in soil over time. The phase relationships between the two indices (SPI and PDSI) show that for periods of less than about a year, the PDSI lags the SPI, and for periods of about a year, the two indices are in phase (Guttman, 1998), in this case both indices reach the highest correlation. Furthermore, other authors have demonstrated near equivalence between the PDSI and the SPI on time scales of 9 to 12 months in Europe (Lloyd-Hughes and Saunders, 2002).

Soil Moisture Index $(\mathrm{iHI})$ and three-month Soil Moisture Index (iHI-3) indicate the relative amount of water in the soil. This available amount of water affects the development of vegetation, so these indices are related to the vegetation index (iNDVI). The best correlation found in both systems was between $\mathrm{iHI}-3$ and iNDVI, $r=0.54$ in the Turia and $r=0.55$ in the Júcar. On the other hand, the $i H I$ is related to the pattern of accumulated rainfall in three months (SPI-3; $r=0.79$ Turia and $r=0.82$ Júcar) and also correlates moderately with the PDSI ( 0.59 and 0.67 , respectively in Turia and Júcar systems), and then the three months moisture index (iHI-3) is related to six-month accumulated rainfall (SPI-6; $r=0.80$ Turia and $r=0.85$ Júcar) and also with the PDSI (0.68 and 0.74). The pair iHI-3/SPI-6 has a slightly better behaviour than the pair iHI/SPI-3. This behaviour has been detected as well in the rest of the water resources systems studied. As results show, the $\mathrm{iHI}$ or the $\mathrm{iHI}-3$ are correlated with the edaphic drought indicator of PALMER but are not the same. PALMER index is more correlated with long-term precipitation SPI-12 than with the soil moisture in a month or in a season.

The vegetation indices derived from observed data by satellite, iNDVI, iNDVI-3, iNDVI-6, have the higher relationships (respectively Turia and Júcar), in all the cases, the six-month accumulated index iNDIVI-6 with the indices: SPI-12 ( $r=0.63$ and $r=0.68)$, PDSI ( $r=0.61$ and $r=0.55)$ and iSI $(r=0.62$ and $r=0.53)$. The six-month iNDVI (iNDVI-6) better correlates with the indices, long-term SPI and PDSI and iSI, than the 
iNDVI-3 and iNDVI. Small variations between the results obtained including and non-including the irrigation land (iNDVI and iNDVI $\mathrm{I}_{\mathrm{W}}$ ) were observed, due to the relative smaller size of the irrigation land in relation to the total surface of the water resources system.

\begin{tabular}{|c|c|c|c|c|c|c|c|c|c|c|c|}
\hline Turia & iSI & SPI-24 & SPI-12 & SPI-6 & SPI-3 & PDSI & iHI & iHI-3 & iNDVI & iNDVI-3 & iNDVI-6 \\
\hline iSI & 1.00 & $\mathbf{0 . 8 1}$ & 0.63 & 0.36 & 0.26 & 0.72 & 0.27 & 0.38 & 0.47 & 0.55 & $\mathbf{0 . 6 2}$ \\
\hline SPI-24 & & 1.00 & 0.76 & 0.54 & 0.41 & 0.86 & 0.38 & 0.45 & 0.45 & 0.50 & 0.54 \\
\hline SPI-12 & & & 1.00 & 0.69 & 0.49 & $\mathbf{0 . 8 9}$ & 0.49 & 0.60 & $\mathbf{0 . 5 6}$ & $\mathbf{0 . 6 1}$ & $\mathbf{0 . 6 3}$ \\
\hline SPI-6 & & & & 1.00 & 0.72 & 0.74 & 0.73 & $\mathbf{0 . 8 0}$ & 0.48 & 0.44 & 0.32 \\
\hline SPI-3 & & & & & 1.00 & 0.58 & $\mathbf{0 . 7 9}$ & 0.77 & 0.45 & 0.25 & 0.10 \\
\hline PDSI & & & & & & 1.00 & 0.59 & $\mathbf{0 . 6 8}$ & $\mathbf{0 . 5 8}$ & $\mathbf{0 . 6 1}$ & $\mathbf{0 . 6 1}$ \\
\hline iHI & & & & & & & 1.00 & 0.81 & 0.40 & 0.23 & 0.14 \\
\hline iHI-3 & & & & & & & & 1.00 & $\mathbf{0 . 5 4}$ & 0.44 & 0.29 \\
\hline iNDVI & & & & & & & & & 1.00 & 0.81 & 0.71 \\
\hline iNDVI-3 & & & & & & & & & & 1.00 & 0.89 \\
\hline iNDVI-6 & & & & & & & & & & & 1.00 \\
\hline Júcar & iSI & SPI-24 & SPI-12 & SPI-6 & SPI-3 & PDSI & iHI & iHI-3 & iNDVI & iNDVI-3 & iNDVI-6 \\
\hline iSI & 1.00 & $\mathbf{0 . 6 2}$ & 0.43 & 0.26 & 0.15 & 0.57 & 0.27 & 0.33 & 0.39 & 0.46 & $\mathbf{0 . 5 3}$ \\
\hline SPI-24 & & 1.00 & 0.67 & 0.44 & 0.31 & 0.76 & 0.43 & 0.47 & 0.32 & 0.36 & 0.45 \\
\hline SPI-12 & & & 1.00 & 0.72 & 0.48 & $\mathbf{0 . 8 4}$ & 0.55 & 0.64 & $\mathbf{0 . 5 3}$ & $\mathbf{0 . 6 0}$ & $\mathbf{0 . 6 8}$ \\
\hline SPI-6 & & & & 1.00 & 0.72 & 0.73 & 0.77 & $\mathbf{0 . 8 5}$ & 0.52 & 0.49 & 0.43 \\
\hline SPI-3 & & & & & 1.00 & 0.55 & $\mathbf{0 . 8 2}$ & 0.78 & 0.45 & 0.28 & 0.19 \\
\hline PDSI & & & & & & 1.00 & 0.67 & $\mathbf{0 . 7 4}$ & $\mathbf{0 . 4 9}$ & $\mathbf{0 . 5 2}$ & $\mathbf{0 . 5 5}$ \\
\hline iHI & & & & & & & 1.00 & 0.83 & 0.39 & 0.24 & 0.19 \\
\hline iHI-3 & & & & & & & & 1.00 & $\mathbf{0 . 5 5}$ & 0.46 & 0.34 \\
\hline iNDVI & & & & & & & & & 1.00 & 0.79 & 0.68 \\
\hline iNDVI-3 & & & & & & & & & & 1.00 & 0.88 \\
\hline iNDVI-6 & & & & & & & & & & & 1.00 \\
\hline
\end{tabular}

Table 4. Correlations between standardised drought indices in the Turia and Júcar basins

The main correlation structure between indices is summarised as follows: the operational drought index iSI is well correlated with long-term meteorological indices SPI-24 or SPI-12; the vegetation index iNDVI-6 with both indices SPI-12 and PDSI, which also is consistent due to the high correlation between them, PDSI with SPI-12; soil moisture iHI with short-term meteorological index SPI-3. The correlations between these indices are calculated for the nine water resources systems (Table 5), which include different climate systems. Annual precipitation, annual potential evapotranspiration and coefficient of variation -CVcorrespond with the period 1980/81-2011/12 (CHJ, 2015) and are used to determine the climate of each system. Based on the aridity index classification (UNEP 1992) - defined as the ratio of annual values of precipitation and potential evapotranspiration P/PET - the systems are classified (in humid systems (P/PET >0.65): Cenia, Mijares with low variability ( $C V=0.23-0.25)$, and Serpis and Marina Alta with high variability ( $\mathrm{CV}=0.30-0.32$ ); sub-humid systems (P/PET 0.65-0.50): Palancia, Turia, and Júcar; and a semiarid systems (P/PET 0.50-0.20): Marina Baja and Vinalopó.

There is a good relationship between the soil moisture index iHI and the short-term meteorological index SPI-3 for all the climate conditions: humid with low variability $(0.82-0.83)$, humid with high variability $(0.77-$ 0.79 ), sub-humid (0.79-0.82) and semiarid (0.71-0.77). This relationship is slightly better for humid and sub-humid conditions than for semiarid conditions. 
A similar behaviour occurs between PDSI and SPI-12 for the different climates, humid with low variability $(0.85-0.86)$ humid with high variability (0.83), sub-humid (0.84-0.89) and semiarid (0.66-0.69). The correlation between both indices is better for humid and sub-humid climates than for semiarid ones.

The vegetation greenness that is better reproduced is the six-month iNDVI (iNDVI-6). The correlation of iNDVI-6 with SPI-12 or SPI-24 and PDSI is better in the semiarid climate, where the available amount of water is a limiting factor to the vegetation development. In this case the correlation ranges from 0.53 to 0.61 using the SPI and ranges from 0.59 to 0.76 using the PDSI. In humid climate conditions, the relationship between the vegetation development (iNDVI-6) and the best correlated meteorological index (SPI-6: 0.32-0.38) or the edaphic index PDSI (0.24-0.39) have the worse values, due to the fact that the available water is not a limiting factor to the vegetation development in these areas.

Current operation drought index iSI, defined by the Júcar RBD Authority, is best correlated with long-term meteorological indices, SPI-12 medium size systems (from $607 \mathrm{~km}^{2}$ of Marina Baja to $4819 \mathrm{~km}^{2}$ of Mijares) and SPI-24 for the largest systems Turia $\left(7234 \mathrm{~km}^{2}\right)$ and Júcar $\left(22,187 \mathrm{~km}^{2}\right)$. Then, the concept of "prolonged drought" established in the WFD and required by the European Commission (EC, 2007) based on SPI in medium size systems is reasonably adjusted to the Status Index currently applied by the Spanish River Basin Authorities. However, the use of this type of indices does not reflect well the complexity of a large basin, such as the case of the Júcar system, where the spatial variability and the water management have a significant role in the amount of available water for the users, agricultural, industrial and urban users. And therefore an index as the SPI has difficulty in capturing the real situation of a large water resources system.

\begin{tabular}{|c|c|c|c|c|c|c|c|c|c|c|}
\hline System & $\begin{array}{c}\text { Surface } \\
\left(\mathrm{km}^{2}\right)\end{array}$ & $\begin{array}{c}P \\
\text { (mm/year) }\end{array}$ & $\begin{array}{c}\text { PET } \\
\text { (mm/year) }\end{array}$ & P/PET & $\begin{array}{l}i H I / \\
\text { SPI-3 }\end{array}$ & $\mathrm{Cv}$ & $P D S I / S P I$ & iNDVI-6 /SPI & $\begin{array}{c}\text { iNDVI-6/- } \\
\text { PDSI }\end{array}$ & iSI - SPI \\
\hline Mijares-Plana Castellón & 4,819 & 534.2 & 826.5 & 0.65 & 0.83 & 0.23 & 0.85 (SPI-12) & 0.32 (SPI-6) & 0.39 & 0.68 (SPI-12) \\
\hline Turia & 7,234 & 457.8 & 833.6 & 0.55 & 0.79 & 0.22 & 0.89 (SPI-12) & 0.61 (SPI-12) & 0.61 & 0.81 (SPI-24) \\
\hline Júcar & 22,187 & 475.2 & 926.6 & 0.51 & 0.82 & 0.22 & 0.84 (SPI-12) & 0.68 (SPI-12) & 0.55 & 0.62 (SPI-24) \\
\hline Serpis & 985 & 691.9 & 963.5 & 0.72 & 0.79 & 0.30 & 0.83 (SPI-12) & 0.63 (SPI-24) & 0.59 & 0.80 (SPI-12) \\
\hline Vinalopó-Alacantí & 2,948 & 339.5 & 959.2 & 0.35 & 0.77 & 0.28 & 0.69 (SPI-12) & 0.53 (SPI-12) & 0.76 & 0.89 (SPI-12) \\
\hline Global: Júcar RBD & 42,735 & 486.5 & 902.0 & 0.54 & 0.82 & 0.21 & 0.84 (SPI-12) & 0.64 (SPI-12) & 0.63 & 0.78 (SPI-24) \\
\hline
\end{tabular}

Table 5. Annual precipitation, potential evapotranspiration, aridity index, coefficient of variation and correlations between iHI/SPI-

3, PDSI/best correlated SPI, iNDVI-6/best correlated SPI and iNDVI-6/PDSI and iSI/best correlated SPI, for the nine water resources systems. The colours mean: blue, humid climate; green, sub-humid climate; and orange, semiarid climate. 


\section{Conclusions}

A set of distributed drought indices is applied to the Júcar River Basin District (RBD) (42735 km²). The Júcar RBD is characterised as a transition zone between humid climate and arid climate, so these indices have been tested in humid, sub-humid and semiarid climate conditions. The indices used are: meteorological indices: different accumulations of the Standardised Precipitation Index (SPI); edaphic indices: Palmer Drought Severity Index (PDSI) and a new index of soil moisture, Humidity Index (HI); a vegetation index, Normalised Difference Vegetation Index (NDVI) and an operational drought index, Status Index (SI). All these indices are standardised to analyse the relationship between them.

The use of drought indices support water managers and final users to understand what is the real situation in the river basin, the evolution of the drought and what areas are more impacted by drought. It is necessary to complement the numerical evolution of drought indicators by water resources systems, with distributed maps that explain if there are any areas with specific problems, which are not adequately included in the global index of the system. Especially, in large basins, such as the Júcar River Basin, the deviations could be significant. Both methods are recommended: a global indicator for a water resources system with the drought evolution along time and a distributed map to better understand the real situation in the water resources system.

The new index, Standardised Humidity Index $(\mathrm{iHI})$, represents the soil moisture state in relation with the normal conditions in this area, and indicates if the status of the soil is very dry, dry, normal, wet or very wet in each month. The 3-mont index iHI-3 indicates the amount of water in the soil during a season. As the vegetation development depends on the amount of available water and others factors, this index can give information about the potential development of the vegetation. The correlation obtained between the $\mathrm{iHI}-3$ and the iNDVI is 0.54 for the Turia and 0.55 for the Júcar system. Besides the status of the soil demonstrated that is highly correlated with the precipitation of the last 3 months, as the correlation between $\mathrm{iHI}$ and SPI reach the highest values for SPI-3. This relationship is slightly better for humid and sub-humid conditions than for semiarid conditions.

The concept of "prolonged drought" established in the WFD and required by the European Commission $(E C, 2007)$ based on the use SPI, has been demonstrated to reproduce the operational drought in medium size river basins of the Júcar RBD. However, the use of this type of indices does not reflect well the complexity of a large basin, such as the case of the Júcar system, where the spatial variability and the water management have a significant role in the status of the system, and other complementary data are necessary, such as drought maps. The best correlated long-term meteorological indices are: SPI-12 for medium size systems (from $607 \mathrm{~km}^{2}$ of Marina Baja to $4819 \mathrm{~km}^{2}$ of Mijares) and SPI-24 for the largest systems Turia $\left(7234 \mathrm{~km}^{2}\right)$ and Júcar $(22,187$ km²).

The iNDVI maps indicate the vegetation activity, greenness, and the iNDVI-3 or iNDVI-6 maps indicate the vegetation activity during a season or two seasons. These maps are the standardisation of the NDVI from the satellite EOS-Aqua with MODIS sensor. The correlation of iNDVI-6 with SPI-12 or SPI-24 (0.53-0.61) and PDSI (0.59-0.76) is better in the semiarid climate, where the available amount of water is a limiting factor to the vegetation development.

A combination of short-term and long-term, drought indices is recommended for a Drought Indicator System in a large river basin. The early drought detection requires the short-term indices. The indices that have shown greater ability for the early detection of droughts have been the SPI-3, iHI and iNDVI. These indices are the first to detect the onset of a dry period (October 2004, June 2009, August 2011), with an estimated anticipation of 5 to 8 months compared to the SPI-12 and PDSI, (October 2004, August 2011), and of 10 to 18 months when is compared to the SPI-24 (October 2004, August 2011). On the other hand, 
long-term indices have been proved to be the most efficient to define the operational drought iSI or the "prolonged drought", such as: SPI-12 or SPI-24, PDSI, iH-3 or iNDVI-6. 


\section{References}

Andreu J, Solera A, Paredes-Arquiola J, Haro-Monteagudo D and van Lanen H. (2015) Drought Project: Research and Science-Policy Interfacing (Eds) Taylor \& Francis Group, London, ISBN 978-1-138-02779-4

CEDEX (1999) Máximas lluvias diarias en la España Peninsular

CHJ (2015) Plan Hidrológico de la Demarcación Hidrográfica del Júcar. Ciclo de planificación hidrológica 2015-2021.

CHJ (2016) Seguimiento del Plan Hidrológico del Júcar. Ciclo de planificación hidrológica 2009 2015. Año hidrológico 2014-2015

Breuning, M., Kriegel, H., Ng, R.T, and Sander. J. (2000) LOF: Identifying density-based local outliers. In Proceedings of the ACM SIGMOD International Conference on Management of Data.

Cleveland, R.B., Cleveland, W.S., McRae, J.E. and Terpenning I., (1990) "STL: A seasonal-trend decomposition procedure based on LOESS", Journal of Official Statistics, Vol. 6, No 1, pp.3-73.

Estrela T and Vargas E (2011) Drought managements Plans in the European Union. The Case of Spain (Eds) Water Resour Manage DOI 10.1007/s11269-011-9971-2

Estrela T, Pérez-Martín MA, Vargas E (2012) Impacts of climate change on water resources in Spain (Eds) Hydrological Sciences Journal, 57 (6), 1-14

Estrela T and Sancho TA (2016) Drought management policies in Spain and the European Union: from traditional emergency actions to Drought Management Plans

EC (2007) Drought management plan report. Including agricultural, drought indicators and climate change aspects. Technical report - 2008 - 023. European Commission

Ferrer J, Pérez-Martín MA, Jiménez S, Estrela T, Andreu J (2012) GIS-based models for water quantity and quality assessment in the Júcar River Basin, Spain, including climate change effects

Guttman NB (1998). Comparing the Palmer drought index and the standardised precipitation index. Journal of the American Water Resources Association 34, 113-121.

Jordan, C.F., 1969. Derivation of leaf-area index from quality of light on the forest floor. Ecology, 50, 663-666.

Lloyd-Hughes B and Saunders MA (2002). A drought climatology for Europe. Int. J. Climatol.22, 15711592.

McKee, TB, Doeskin NJ, Kleist J, (1993) The relationship of drought frequency and duration to time scales. Proc. 8th Conf. on applied climatology, January 17-22, 1993, American Meteorological Society, Boston, Massachusetts, pp.179-184

MMA (2007) Ministerio de Medio Ambiente. Orden MAM/698/2007, de 21 de marzo, por la que se aprueban los planes especiales de actuación en situaciones de alerta y eventual sequía en los ámbitos de los planes hidrológicos de cuencas intercomunitarias

Mishra AK and Singh VP (2010) A review of drought concepts (Eds) J. Hydrol. 391 (2010) 202-216

Palmer WC (1965) Meteorological Drought. Research Paper No 45 p 58. US Department of Commerce, Weather Bureau, Washington, D.C.

Pedro-Monzonís M, Solera A, Ferrer J, Estrela T, Paredes-Arquiola J (2015) A review of water scarcity and drought indexes in water resources planning and management (Eds) J. Hydrol. 527 (2015), 482-49 
Pérez-Martín MA, Estrela T, Andreu J and Ferrer J. (2014) Modeling Water Resources and RiverAquifer Interaction in the Júcar River Basin, Spain. Water Resour Manage (2014) 28:4337-4358 DOI 10.1007/s11269-014-0755-3

Pérez-Martín MA, Batán A, del-Amo P, Moll S. (2015) Climate change impact on water resources and droughts of AR5 scenarios in the Jucar River, Spain. Drought: Research and Science-Policy Interfacing - Proceedings of the International Conference on Drought: Research and SciencePolicy Interfacing pp. 189-195. DOI: 10.1201/b18077-32

Pérez-Martín MA, Estrela T, del-Amo P. (2016) Measures required to reach the nitrate objectives in groundwater based on a long-term nitrate model for large river basins (Júcar, Spain). Science of the Total Environment 566-567 (2016) 122-133. doi:10.1016/j.scitotenv.2016.04.206

Quiring SM, Ganesh S (2010) Evaluating the utility of the Vegetation Condition Index (VCI) for monitoring meteorological drought in Texas (Eds) Agricultural and Forest Meteorology 150 (2010) 330-339.

Salas JD, Delleur JW, Yevjevich V, Lane WL (1980) Applied modeling of hydrologic time series (Eds) Water Resources publications

Sivakumar MVK, Wilhite DAW, Svoboda MD, Hayes M, Motha R (2011). Drought risk and meteorological droughts. Global Assessment Report (GAR)

UNEP (1992) World Atlas of Desertification. Edward Arnold. London

Vicente-Serrano S.M., Santiago Beguería, Juan I. López-Moreno, (2010) A Multi-scalar drought index sensitive to global warming: The Standardized Precipitation Evapotranspiration Index - SPEI. Journal of Climate 23: 1696-1718.

Wilhite DA and Buchanan-Smith M (2005) Drought as Hazard: Understanding the Natural and Social Context. In: Wilhite DA (Ed) Drought and Water Crisis. Science, Technology, and Management Issues. CRC Press Taylor and Francis. pp 3-29 